
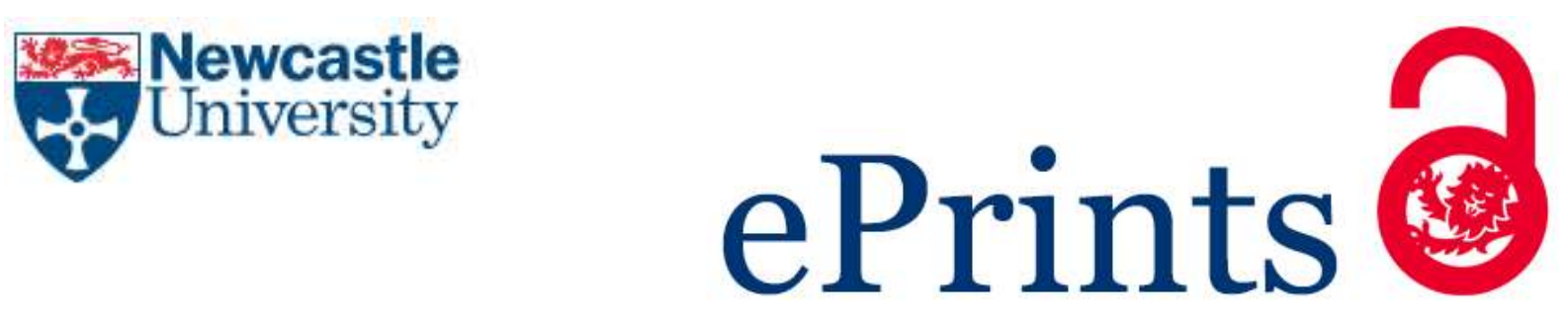

Jiang L, Roskilly AP, Wang RZ, Wang LW, Lu YJ. Analysis on innovative modular sorption and resorption thermal cell for cold and heat cogeneration. Applied Energy 2017, 204, 767-779.

Copyright:

(C) 2017. This manuscript version is made available under the CC-BY-NC-ND 4.0 license

DOI link to article:

https://doi.org/10.1016/i.apenergy.2017.07.041

Date deposited:

$15 / 08 / 2017$

Embargo release date:

01 August 2018

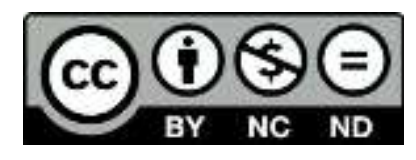

This work is licensed under a

Creative Commons Attribution-NonCommercial-NoDerivatives 4.0 International licence 


\title{
Analysis on innovative modular sorption and resorption thermal cell for cold and heat cogeneration
}

\author{
L. Jiang ${ }^{\mathrm{a}, \mathrm{b},{ }^{*}}$, A.P. Roskilly ${ }^{\mathrm{b}}$, R.Z. Wang ${ }^{\mathrm{a}}$, L.W. Wang ${ }^{\mathrm{a}}$, Y.J. Lu ${ }^{\mathrm{b}}$ \\ ${ }^{a}$ Institute of Refrigeration and Cryogenics, Shanghai Jiao Tong University, Shanghai, 200240, China \\ ${ }^{b}$ Sir Joseph Swan Centre for Energy Research, Newcastle University, Newcastle NE1 7RU, UK
}

\begin{abstract}
Innovative modular sorption and resorption thermal cell are presented for cold and heat cogeneration.
Expanded natural graphite treated with sulfuric acid is selected in the development of composite sorbents for improved heat and mass transfer performance. It is indicated that thermal conductivity and permeability range from $11.9 \mathrm{~W} \cdot \mathrm{m}^{-1} \cdot \mathrm{K}^{-1}$ to $36.5 \mathrm{~W} \cdot \mathrm{m}^{-1} \cdot \mathrm{K}^{-1}$ and from $1.04 \times 10^{-14} \mathrm{~m}^{2}$ to $8.02 \times 10^{-11} \mathrm{~m}^{2}$. Sorption characteristics of composite sorbents are also investigated. Results demonstrate that $\mathrm{MnCl}_{2}-\mathrm{CaCl}_{2}-\mathrm{NH}_{3}$ reveals the best sorption performance under the condition of $130^{\circ} \mathrm{C}-150^{\circ} \mathrm{C}$ heat source temperature and $-20^{\circ} \mathrm{C}-5^{\circ} \mathrm{C}$ evaporation temperature. Sorption quantities of sorption and resorption working pairs range from $0.169 \mathrm{~kg} \cdot \mathrm{kg}^{-1}$ to $0.499 \mathrm{~kg} \cdot \mathrm{kg}^{-1}$. Based on testing results, energy density and power density of modular resorption thermal cell are compared with that of sorption thermal cell. Results indicate that heat density ranges from $580 \mathrm{~kJ} \cdot \mathrm{kg}^{-1}$ to $1368 \mathrm{~kJ} \cdot \mathrm{kg}^{-1}$ whereas cold density ranges from $400 \mathrm{~kJ} \cdot \mathrm{kg}^{-1}$ to $1134 \mathrm{~kJ} \cdot \mathrm{kg}^{-1}$. Simultaneously, heat and cold power density range from 322 $\mathrm{W} \cdot \mathrm{kg}^{-1}$ to $1502 \mathrm{~W} \cdot \mathrm{kg}^{-1}$ and from $222 \mathrm{~W} \cdot \mathrm{kg}^{-1}$ to $946 \mathrm{~W} \cdot \mathrm{kg}^{-1}$. Both sorption and resorption thermal cell have their own advantages, which are flexible connected for scaling applications.
\end{abstract}

Keywords: Composite sorbent, Heat and mass transfer performance, Sorption characteristic, Resorption thermal cell

\footnotetext{
* Corresponding author. Tel. +86-21-34206309
}

Email: maomaojianglong@sjtu.edu.cn (L.Jiang) 


\section{Nomenclature}

A

$\mathrm{BaCl}_{2}$

C

$C D$

$\mathrm{CaCl}_{2}$

ENG

ENG-TSA

$H D$

HTS

LTS

$\mathrm{MnCl}_{2}$

$\mathrm{NH}_{4} \mathrm{Cl}$

$P$

$P D$

$Q$

$\mathrm{R}$

RTES

$\mathrm{SrCl}_{2}$

STES

TES

$t$

$x$

\section{Greek letters}

$$
\begin{aligned}
& v^{\prime} \\
& v^{\prime \prime}
\end{aligned}
$$

\section{Subscripts}

Area of ammonia vessle $\left(\mathrm{m}^{2}\right)$

Barium chloride

Specific heat $\left(\mathrm{J} \cdot \mathrm{g}^{-1} \cdot \mathrm{K}^{-1}\right)$

Cold density $\left(\mathrm{kJ} \cdot \mathrm{kg}^{-1}\right)$

Calcium chloride

Expanded natural graphite

Expanded natural graphite treated with sulfuric acid

Heat density $\left(\mathrm{kJ}^{\mathrm{kg}} \mathrm{kg}^{-1}\right)$

High temperature salt

Low temperature salt

Manganese chloride

Ammonium chloride

Pressure $(\mathrm{Pa})$

Power density $\left(\mathrm{W} \cdot \mathrm{kg}^{-1}\right)$

Heat $(\mathrm{kJ})$

Gas constant $\left(\mathrm{J} \cdot \mathrm{kg}^{-1} \cdot \mathrm{K}^{-1}\right)$

Resorption thermal energy storage

Stronium chloride

Sorption thermal energy storage

Thermal energy storage

Time (s)

Sorption quantity $\left(\mathrm{kg} \cdot \mathrm{kg}^{-1}\right)$

Specific volume of saturated liquid ammonia $\left(\mathrm{m}^{3} \cdot \mathrm{kg}^{-1}\right)$

Specific volume of saturated vapor ammonia $\left(\mathrm{m}^{3} \cdot \mathrm{kg}^{-1}\right)$

C

Cold 


$\begin{array}{ll}\text { con } & \text { Condensation } \\ \text { d } & \text { Desorption } \\ \text { eq } & \text { Equilibrium } \\ \text { eva } & \text { Evaporation } \\ \text { h } & \text { Heat } \\ \text { in } & \text { Input } \\ \text { out } & \text { Output } \\ \text { res } & \text { Resorption } \\ \text { s } & \text { Sorption } \\ \text { sor } & \text { Sorbent }\end{array}$

\section{Introduction}

It is extensively acknowledged that thermal energy storage (TES) is one of the key technologies for industrial waste heat recovery and renewable energy utilization, which is able to provide a great potential for reducing carbon dioxide emissions $[1,2]$. The promising TES technology has been becoming an urgent issue to overcome the drawbacks of time discrepancy, distance discrepancy and instability of renewable energy by adjusting mismatch between energy supply and demand[3,4].

The most common TES methods are sensible heat storage and latent heat storage. Sensible heat storage lies in heat exchanging process between energy storage materials i.e. concrete[5], pebble[6] and heat exchanging fluid such as water, molten salt[7] or oil[8]. Sensible heat storage technology has the disadvantages of relatively low thermal storage efficiency and large system volume. Compared with sensible heat storage, a higher thermal storage capacity could be obtained by latent heat storage. Latent heat storage systems depend on heat charging and discharging during phase change process of phase change materials (PCMs) such as paraffin wax[9], $\mathrm{CaCl}_{2} \cdot \mathrm{H}_{2} \mathrm{O}[10]$ and $\mathrm{Na}_{2} \mathrm{SO}_{4} \cdot 10 \mathrm{H}_{2} \mathrm{O}$ [11]. Efficiency of latent heat storage systems is mainly determined by selections of PCMs and geometric design of storage systems[12]. Both sensible and latent heat storage are verified to have a low energy storage density and unacceptable heat loss for both short term and long term storage[13]. Moreover, latent heat storage takes a risk of releasing its stored energy ahead of time, resulting in large heat losses 
during the storage duration. It is the time to seek for another feasible TES method with an improved performance.

In recent years, chemisorption process has been gradually applied to TES technology[14]. Sorption thermal energy storage (STES) has the advantages of high energy storage density, good capability of short term and long term energy storage and flexible working modes i.e. direct heat supply[15], cold and heat cogeneration to supply useful cold and heat simultaneously[16] as well as energy upgrade to upgrade the quality of low-grade thermal energy[17]. STES technology characterized as compact structure and high efficiency has been considered to be a prospective solution to long term or seasonal TES[18]. The external heat source promotes the decomposition of sorption work pair, and energy could be stored in forms of chemical potentials. When sorbate and sorbent come to react again, heat and cold could be released in exothermic process. In this process, energy could then be stored without heat loss as long as sorbent and sorbate could be kept separate[19]. These distinguished traits make STES superior to other TES forms. In order to discriminate the difference between STES and conventional sensible, latent heat energy storage as well as other thermochemical energy storage technologies, a novel sorption thermal battery is proposed [20]. The concept of thermal battery is analogous to electric battery. Temperature difference provided by thermal battery is similar with voltage difference supplied by electric battery[21]. Similarly, thermal energy could be compared to current. However, it is widely acknowledged that electrical battery consists of several cells. Likewise, sorption thermal battery should be composed of sorption thermal cells.

Sorption thermal cell is defined as a modular TES unit which is significant for scaling utilizations of sorption thermal battery. With regard to electric cell, charging and discharging rate are usually key parameters. Heat charging and discharging rate of sorption thermal cell also play leading roles, which are greatly determined by heat and mass transfer performance and sorption characteristics. Composite sorbent is considered as a common method to solve the problems of swelling and agglomeration of granular salts, which could improve sorption and desorption rate [22, 23]. Expanded natural graphite (ENG)[23, 24], carbon nanoparticle[25] and vermiculite[26] have attempted to be selected as matrix for developing composite sorbents, which are conducive to the overall heat and mass transfer performance. Different sorption working pairs of composite sorbents are investigated by various researchers[27]. Among them, $\mathrm{CaCl}_{2}-\mathrm{NH}_{3}$ working pair has been widely investigated for STES, air conditioning and ice maker due to its thermal and sorption stability[28]. For medium and low temperature waste heat utilization, $\mathrm{MnCl}_{2}-\mathrm{NH}_{3}$ is another good selection due to its proper equilibrium desorption and sorption temperature[29]. Compared with conventional sorption working pair, resorption working pair is usually expected to have a higher performance for resorption thermal energy storage (RTES) with improved safety and system compactness[30]. 
$\mathrm{MnCl}_{2}$ is often selected as high temperature salt (HTS) due to its low causticity and suitable desorption temperature whereas various low temperature salts (LTSs) such as $\mathrm{NH}_{4} \mathrm{Cl}, \mathrm{CaCl}_{2}, \mathrm{SrCl}_{2}$ and $\mathrm{BaCl}_{2}$ etc. are investigated for the optimal match[31, 32]. In term of resorption working pairs, $\mathrm{MnCl}_{2}-\mathrm{CaCl}_{2}-\mathrm{NH}_{3}$ has been extensively analyzed for different working temperature ranges. Moreover, this resorption working pair could also be applied for refrigerated truck, which demonstrates the flexibility of resorption process[33].

Nonetheless, less research about sorption and resorption thermal cell is reported which is regarded as a potential solution to solar energy storage and utilization. Also there is lack of overall comparison and evaluation between sorption and resorption working pairs for TES application. In this paper, novel modular sorption and resorption thermal cell are developed and analyzed. Composite sorbents are developed with expanded natural graphite treated with sulfuric acid (ENG-TSA) as the matrix for improving heat and mass transfer performance. Sorption characteristics are also investigated and compared. Based on testing results, resorption thermal cell is further evaluated and compared with sorption thermal cell for cold and heat cogeneration.

\section{Development of composite sorbents with enhanced thermal conductivity}

For different metal chlorides, $\mathrm{MnCl}_{2}$ is chosen as $\mathrm{HTS}$ whereas $\mathrm{CaCl}_{2}, \mathrm{SrCl}_{2}$ and $\mathrm{NH}_{4} \mathrm{Cl}$ are selected as LTSs. Reaction processes of these salts with ammonia could be according to equations 1-6. Table 1 indicates the main parameters of selected salts in term of $30^{\circ} \mathrm{C}$ heat sink temperature, which is composed of molar mass, equilibrium desorption temperature, reaction enthalpy and maximum cycle sorption quantity. To simplify the description of chemisorption processes of different sorbents, phrases of $\mathrm{MnCl}_{2} 6 / 2, \mathrm{CaCl}_{2} 8 / 4, \mathrm{SrCl}_{2} 8 / 1, \mathrm{CaCl}_{2} 4 / 2$ and $\mathrm{NH} \mathrm{Hl}_{4}$ $3 / 0$ are used in this paper. For example, $\mathrm{MnCl}_{2} 6 / 2$ represents the process in which $\mathrm{MnCl}_{2}$ ammoniate reacts with ammonia from 2 moles to 6 moles. Among these chlorides, $\mathrm{CaCl}_{2}$ proceeds two reaction processes of $\mathrm{CaCl}_{2} 8 / 4$ and $\mathrm{CaCl}_{2} 4 / 2$ in selected temperature range. The developing process of composite sorbent can be referred to the reference[34]. ENG-TSA is first dried in an oven at a controlled temperature of $120^{\circ} \mathrm{C}$. Then metal chloride, ENGTSA and water will be mixed together. Afterwards, composite sorbent is dried in an oven at a controlled temperature of $120^{\circ} \mathrm{C}$ to remove the water. Then temperature of oven will be further increased to $240^{\circ} \mathrm{C}$ for 
removing crystal water of metal chlorides. Finally composite sorbent will be compressed into block by pressing machine for testing.

Density and mass ratio of salt usually play leading roles in the development of composite sorbents. The crack will easily happen if mass ratio of salt is too low, which results in low specific cooling power (SCP). The higher density usually leads to lower permeability and higher thermal conductivity. In this paper, density of samples is selected as $400 \mathrm{~kg} \cdot \mathrm{m}^{-3}$, which is close to real sorption systems[35]. Mass ratios of salt are in the range from $50 \%$ to $83 \%$. Since anisotropic heat and mass transfer characteristics of consolidated ENG-TSA[36] and composite sorbent[37] have already been investigated, only plate samples i.e. heat and mass transfer performance is perpendicular to compressing direction will be evaluated due to the optimal performance.

$$
\begin{gathered}
\mathrm{MnCl}_{2} \cdot 2 \mathrm{NH}_{3}+4 \mathrm{NH}_{3} \longleftrightarrow \mathrm{MnCl}_{2} \cdot 6 \mathrm{NH}_{3}+4 \Delta H_{\mathrm{MnCl}_{2}} \\
\mathrm{CaCl}_{2} \cdot 2 \mathrm{NH}_{3}+2 \mathrm{NH}_{3} \longleftrightarrow \mathrm{CaCl}_{2} \cdot 4 \mathrm{NH}_{3}+2 \Delta H_{\mathrm{CaCl}_{2}} \\
\mathrm{CaCl}_{2} \cdot 4 \mathrm{NH}_{3}+4 \mathrm{NH}_{3} \longleftrightarrow \mathrm{CaCl}_{2} \cdot 8 \mathrm{NH}_{3}+4 \Delta H_{\mathrm{CaCl}_{2}} \\
\mathrm{SrCl}_{2} \cdot \mathrm{NH}_{3}+7 \mathrm{NH}_{3} \longleftrightarrow \mathrm{SrCl}_{2} \cdot 8 \mathrm{NH}_{3}+7 \Delta H_{\mathrm{SrCl}_{2}} \\
\mathrm{NH}_{4} \mathrm{Cl}+3 \mathrm{NH}_{3} \longleftrightarrow \mathrm{NH}_{4} \mathrm{Cl} \cdot 3 \mathrm{NH}_{3}+3 \Delta H_{\mathrm{NH}_{4} \mathrm{Cl}} \\
\mathrm{NH}_{3}(\mathrm{liq})+\Delta H_{\mathrm{eva}} \longleftrightarrow \mathrm{NH}_{3} \text { (gas) }
\end{gathered}
$$

Table 1. The main parameters of selected sorbents[30].

\begin{tabular}{ccccc}
\hline Salt & $\begin{array}{c}\text { Molar mass } \\
\left(\mathrm{g} \cdot \mathrm{mol}^{-1}\right)\end{array}$ & $\begin{array}{c}\text { Equilibrium desorption } \\
\text { temperature }\left({ }^{\circ} \mathrm{C}\right)\end{array}$ & $\begin{array}{c}\text { Reaction enthalpy } \\
\left(\mathrm{J} \cdot \mathrm{mol}^{-1}\right)\end{array}$ & $\begin{array}{c}\text { Maximum cycle sorption } \\
\text { quantity }\left(\mathrm{kg} \cdot \mathrm{kg}^{-1}\right)\end{array}$ \\
\hline $\mathrm{MnCl}_{2} 6 / 2$ & 125.9 & 152 & 47416 & 0.54 \\
$\mathrm{CaCl}_{2} 4 / 2$ & 110.8 & 97 & 42269 & 0.31 \\
$\mathrm{SrCl}_{2} 8 / 1$ & 158.5 & 95 & 41431 & 0.75 \\
$\mathrm{CaCl}_{2} 8 / 4$ & 110.8 & 86 & 41403 & 0.61 \\
$\mathrm{NH}_{4} \mathrm{Cl} 3 / 0$ & 53.4 & 52 & 27678 & 0.95 \\
\hline
\end{tabular}




\subsection{Thermal conductivity and permeability}

For testing thermal conductivity of selected composite sorbents, laser flash measuring method is adopted. Testing details can be referred to the reference[38]. Permeability of samples is tested by the unit which is specially designed. Ergun model is suitable to be applied in the measurement since there is no compressibility effect [39]. Table 2 demonstrates thermal conductivity and permeability of composite sorbents i.e. $\mathrm{MnCl}_{2}, \mathrm{CaCl}_{2}, \mathrm{SrCl}_{2}$ and $\mathrm{NH}_{4} \mathrm{Cl}$. It is indicated that thermal conductivity increases with the decrease of mass ratio of salt. The highest thermal conductivity could reach $36.5 \mathrm{~W} \cdot \mathrm{m}^{-1} \cdot \mathrm{K}^{-1}$ in term of $50 \%$ mass ratio of $\mathrm{NH}_{4} \mathrm{Cl}$, which is about 100 times higher than that of granular $\mathrm{NH}_{4} \mathrm{Cl}$. For different composite sorbents, thermal conductivity ranges from $11.9 \mathrm{~W} \cdot \mathrm{m}^{-}$ ${ }^{1} \cdot \mathrm{K}^{-1}$ to $36.5 \mathrm{~W} \cdot \mathrm{m}^{-1} \cdot \mathrm{K}^{-1}$ when mass ratio of salt ranges from $50 \%$ to $83 \%$. Permeability of composite sorbents increases with the increase of mass ratio of salt, which ranges from $1.04 \times 10^{-14} \mathrm{~m}^{2}$ to $8.02 \times 10^{-11} \mathrm{~m}^{2}$.

The random error of thermal conductivity is less than $0.1 \%$, and its largest relative error is $5 \%$. The largest relative error of permeability is $15.1 \%$, and its average relative error is $14.7 \%$.

Table 2. Thermal conductivity and permeability of composite sorbents.

\begin{tabular}{|c|c|c|c|c|c|c|}
\hline & \multirow{2}{*}{$\begin{array}{c}\text { Composite } \\
\text { sorbent }\end{array}$} & \multicolumn{5}{|c|}{ Mass ratio of salt } \\
\hline & & $50 \%$ & $67 \%$ & $75 \%$ & $80 \%$ & $83 \%$ \\
\hline \multirow{4}{*}{$\begin{array}{c}\text { Thermal } \\
\text { conductivity } \\
\left(\mathrm{W} \cdot \mathrm{m}^{-1} \cdot \mathrm{K}^{-1}\right)\end{array}$} & $\mathrm{MnCl}_{2}$ & 31.7 & 23.3 & 17.3 & 14.2 & 12.1 \\
\hline & $\mathrm{CaCl}_{2}$ & 34.9 & 24.8 & 18.6 & 14.6 & 11.9 \\
\hline & $\mathrm{SrCl}_{2}$ & 32.3 & 26.9 & 18 & 14.5 & 13.3 \\
\hline & $\mathrm{NH}_{4} \mathrm{Cl}$ & 36.5 & 27.4 & 18.3 & 14.4 & 12.2 \\
\hline \multirow{4}{*}{$\begin{array}{l}\text { Permeability } \\
\qquad\left(\mathrm{m}^{2}\right)\end{array}$} & $\mathrm{MnCl}_{2}$ & $5.14 \times 10^{-14}$ & $7.04 \times 10^{-13}$ & $6.44 \times 10^{-12}$ & $7.97 \times 10^{-11}$ & $8.02 \times 10^{-11}$ \\
\hline & $\mathrm{CaCl}_{2}$ & $4.20 \times 10^{-14}$ & $4.42 \times 10^{-13}$ & $4.90 \times 10^{-12}$ & $7.52 \times 10^{-11}$ & $7.93 \times 10^{-11}$ \\
\hline & $\mathrm{SrCl}_{2}$ & $1.04 \times 10^{-14}$ & $2.06 \times 10^{-13}$ & $1.33 \times 10^{-12}$ & $5.67 \times 10^{-11}$ & $7.55 \times 10^{-11}$ \\
\hline & $\mathrm{NH}_{4} \mathrm{Cl}$ & $1.95 \times 10^{-14}$ & $1.85 \times 10^{-13}$ & $3.95 \times 10^{-12}$ & $3.35 \times 10^{-11}$ & $6.21 \times 10^{-11}$ \\
\hline
\end{tabular}

\subsection{Sorption characteristics}

Sorption characteristics of composite sorbents are investigated by a testing unit as shown in Fig.1. Fig.1a shows the schematic, which is the main part of experimental photo as shown in Fig.1b. This part is highlighted with dash line. The unit is mainly composed of a HTS reactor, a LTS reactor, a refrigerant vessel, a differential pressure transmitter, two pressure sensors, three cryostats i.e. cryostat 1, cryostat 2, cryostat 3 and several valves, 
etc. Refrigerant vessel acts as condenser or evaporator, which is determined by working conditions. Temperature of HTS and LTS reactors are controlled by cryostat 2 and 3 while refrigerant vessel is controlled by cryostat 1 .

Testing procedures of resorption working pairs are as follows:

(1) Connect HTS and LTS reactor by opening V1 and V2 , and perform resorption regeneration and refrigeration processes alternatively by controlling the temperature through cryostat 2 and cryostat 3 . Temperature of HTS and LTS reactor are controlled at set heat source temperature, heat sink temperature and refrigeration temperature. In this process data of pressure inside LTS reactor are recorded.

(2) When HTS and LTS reactor work under the stable condition, close V2 and open V3 to control pressure inside the refrigerant vessel as recorded pressure data of LTS reactor by crostat 1, then ammonia will desorbed from HTS reactor to refrigerant vessel, and record level change of the refrigerant by smart pressure difference transmitter.

In order to compare reaction characteristics between sorption and resorption working pairs, sorption performance of HTS i.e. $\mathrm{MnCl}_{2}$ is also investigated. The concerning testing processes are as follows:

(1) Sorption process: Open valve V1 and V3. Keep the refrigerant vessel at a constant pressure according to set refrigeration temperature by cryostat 1 , and control the temperature of HTS reactor as set heat sink temperature. For each testing point with predetermined sorption temperature, fluid level in refrigerant vessel is recorded by smart differential pressure transmitter.

(2) Desorption process: Similarly the reactor is heated to constant desorption temperature whereas refrigerant vessel is controlled at a constant pressure. Then data of liquid level in refrigerant vessel is recorded.

Sorption quantities could be evaluated according to equation 7 .

$$
\Delta x=\frac{1}{m_{\text {salt }}} \cdot \Delta\left\{\left(1-\frac{v^{\prime}\left(T_{\mathrm{e}}\right)}{v^{\prime \prime}\left(T_{\mathrm{e}}\right)}\right) \cdot \frac{A_{\mathrm{c}}}{g} \cdot \Delta P\right\}
$$


where $m_{\text {salt }}$ is mass of composite sorbents $(\mathrm{kg}), v^{\prime}\left(T_{\mathrm{e}}\right)$ and $v^{\prime \prime}\left(T_{\mathrm{e}}\right)$ are specific volume of saturated liquid ammonia and saturated vapor ammonia $\left(\mathrm{m}^{3} \cdot \mathrm{kg}^{-1}\right), A_{\mathrm{c}}$ is the effective area of cross section of ammonia in the evaporator/condenser $\left(\mathrm{m}^{2}\right), \mathrm{g}$ is gravity acceleration $\left(9.80 \mathrm{~m} \cdot \mathrm{s}^{-2}\right), \Delta P$ is pressure difference in sorption and desorption process $(\mathrm{Pa})$.

Mass of composite sorbent is measured by the balance (BS2202S) with measuring error of $0.01 \mathrm{~g}$. Pressure difference between liquid end and vapor end of evaporator/condenser is measured by a smart differential pressure transmitter with testing error of $0.2 \%$. The relative error of sorption quantity of composite sorbent is $0.37 \%$, which can be calculated by equation 8 .

$$
\left|\frac{d \Delta x}{\Delta x}\right| \leq\left|\frac{d m_{\text {salt }}}{m_{\text {salt }}}\right|+\left[\frac{d\left(\left(1-v^{\prime}\left(T_{\mathrm{e}}\right) / v^{\prime \prime}\left(T_{\mathrm{e}}\right)\right) \cdot\left(A_{\mathrm{c}} / g\right) \cdot \Delta(\Delta p)\right)}{\Delta\left(\left(1-v^{\prime}\left(T_{\mathrm{e}}\right) / v^{\prime \prime}\left(T_{\mathrm{e}}\right)\right) \cdot\left(A_{\mathrm{c}} / g\right) \cdot \Delta(\Delta p)+V / v^{\prime \prime}\left(T_{\mathrm{e}}\right)\right)}\right]
$$

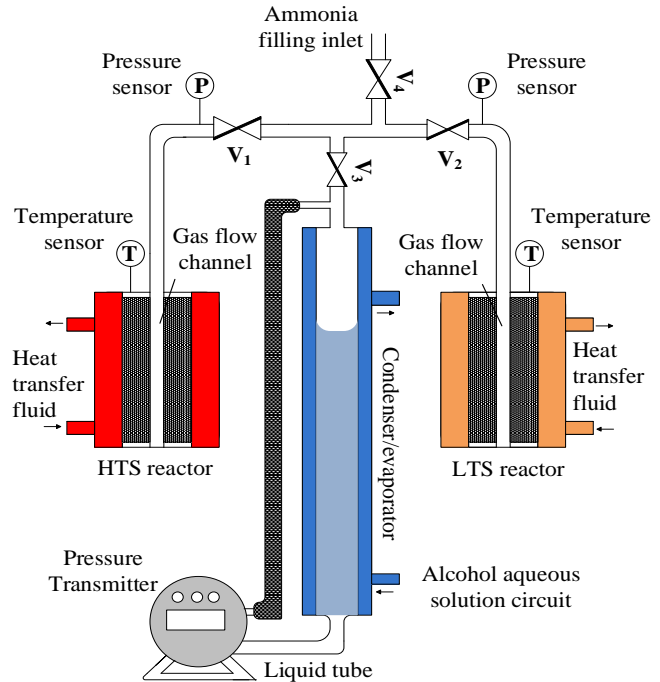

(a)

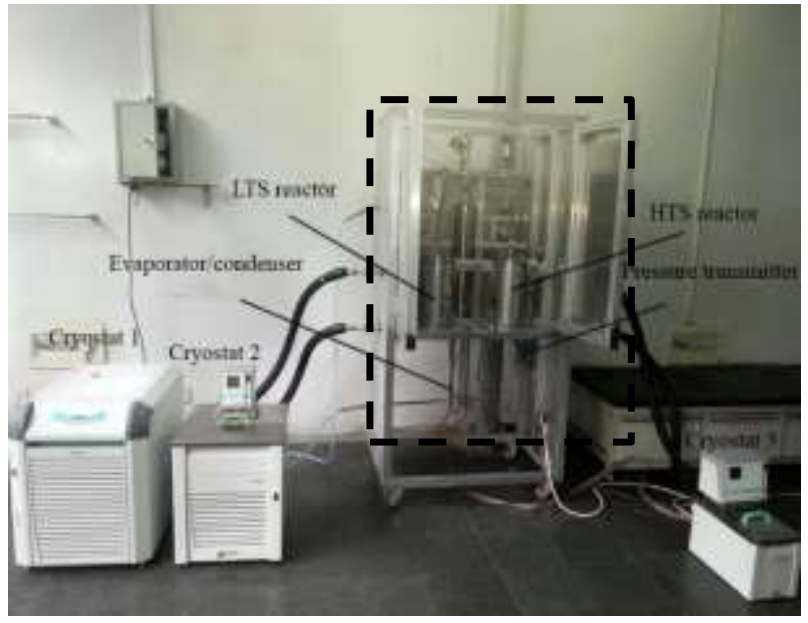

(b)

Fig.1. Testing unit for sorption characteristics (a) schematic; (b) photo. 
Sorption quantity and global conversion rate are two major factors to assess the performance of sorption and resorption working pairs. Sorption quantity reveals the amount of refrigerant that reacts with composite sorbent while global conversion rate is defined as the percentage of composite sorbent that reacts with the refrigerant [40]. In order to have a comprehesive investigation, global conversion rate $\mathrm{X}$ and sorption quantity of different working pairs are evaluated and compared. In the testing process, heat source temperature for resorption working pairs is selected from $130^{\circ} \mathrm{C}$ to $150^{\circ} \mathrm{C}$ which is higher than their equilibiurm desorption temperature. Heat sink temperature ranges from $25^{\circ} \mathrm{C}$ to $35^{\circ} \mathrm{C}$ whereas refrigeration temperature is from $-20^{\circ} \mathrm{C}$ to $5^{\circ} \mathrm{C}$. For $\mathrm{MnCl}_{2}-\mathrm{NH}_{3}$ sorption working pair, testing refrigeration temperature is the same with that of resorption working pairs.

Under the condition of $150^{\circ} \mathrm{C}$ heat souce temeprature, $\mathrm{MnCl}_{2}-\mathrm{CaCl}_{2}-\mathrm{NH}_{3}$ working pair is examplified for futher illustration which is shown in Fig.2. It is indicated that global conversion rate and sorption quantity increase with the increase of refrigeration temeprature and decrease of heat sink temperature. Also worth noting that sorption quantiy and global conversion rate are more sensitive to refrigeration temperature than heat sink temperature. It is demonstrated that global conversion rate varies significantly with the increment of refrigeration temperature, which becomes more prominent in freezing condition than in air conditioning condition. This is mainly because global conversion rate is mainly determined by the driving pressure difference $\left(P_{\mathrm{r}}-P_{\text {eq }}\right)$ between constraining pressure $\left(P_{\mathrm{r}}\right)$ and equilibrium pressure $\left(P_{\mathrm{eq}}\right)$. In the sorption process, sorption reactor is usually cooled by cooling medium at a set temperature, which determines equilibrium reaction pressure $\left(P_{\text {eq }}\right)$. Evaporator is controlled at refrigeration temperature, which determines constraining pressure $\left(P_{\mathrm{r}}\right)$. Therefore, the higher refrigeration temperature is, the larger driving pressure difference becomes, thus leading to the larger global conversion rate. The highest global coversion rate and sorption quantity of $\mathrm{MnCl}_{2}-\mathrm{CaCl}_{2}-\mathrm{NH}_{3}$ are able to reach $93 \%$ and $0.502 \mathrm{~kg} \cdot \mathrm{kg}^{-1}$, respectively. For different heat source temperatures and condensation temperatures, global 
coversion rate and sorption quantity range from $44.6 \%$ to $93 \%$ and $0.241 \mathrm{~kg} \cdot \mathrm{kg}^{-1}$ to $0.502 \mathrm{~kg} \cdot \mathrm{kg}^{-1}$. To further elaborate resorption reaction process, sorption characteristics of $\mathrm{MnCl}_{2}-\mathrm{CaCl}_{2}-\mathrm{NH}_{3}$ are demostrated under the condition of $130^{\circ} \mathrm{C}-150^{\circ} \mathrm{C}$ heat source temperature and $-20^{\circ} \mathrm{C}-5^{\circ} \mathrm{C}$ refrigeration temperature as shown in Fig.3. It is worth noting that heat source tempreature will also have a great influence on sorption performance when heat sink temperature is $30^{\circ} \mathrm{C}$. The reasons are a little different from that of refrigeration temperature. The higher heat source temperature is, the larger driving potentential becomes, which will result in the larger global conversion rate and sorption quantity. Also when heat source temperature decreases and approaches the equilibrium point, sorption performance will decline sharply due to non-equilibrium characteristics of real reaction processes, which demonstrates the limited reduction of desorption temperature through resorption working pair[30].

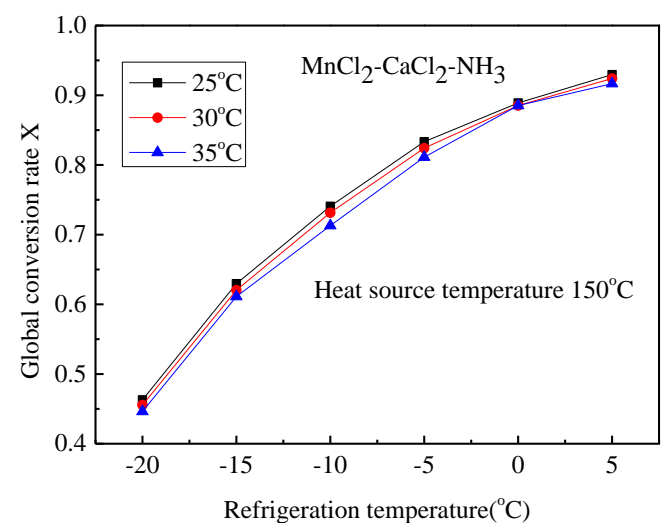

(a)

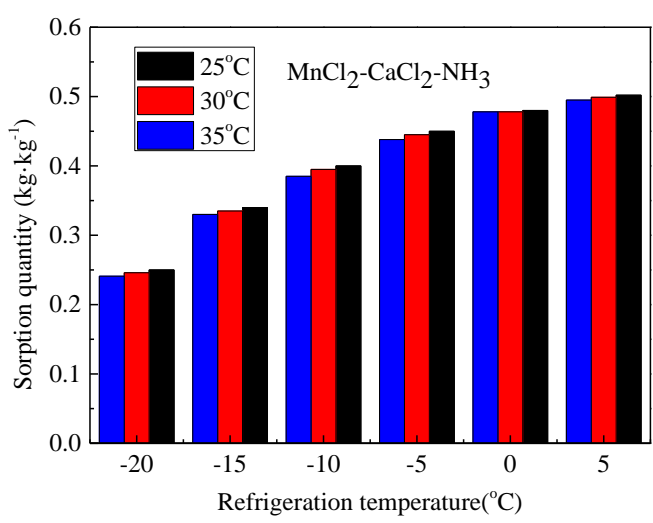

(b)

Fig.2. Sorption characteristic of $\mathrm{MnCl}_{2}-\mathrm{CaCl}_{2}-\mathrm{NH}_{3}$ resorption working pair vs. refrigeration and heat sink temperatures (a) global conversion rate; (b) sorption quantity. 


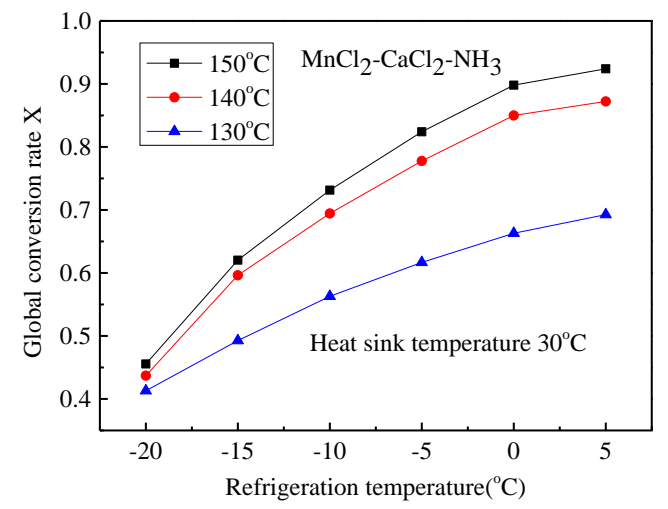

(a)

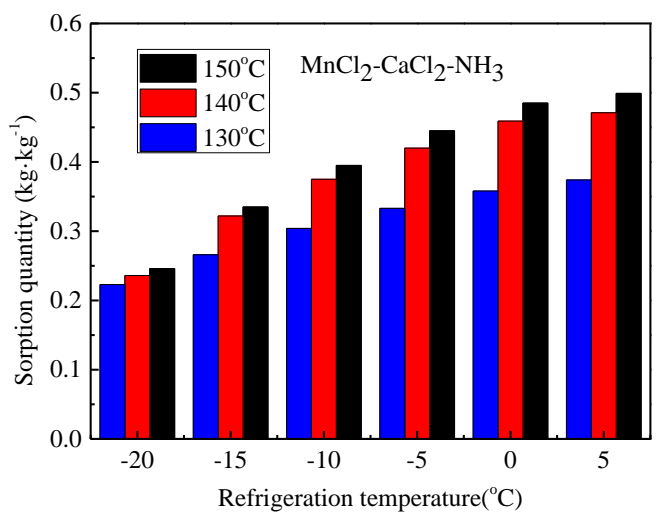

(b)

Fig.3. Sorption characteristic of $\mathrm{MnCl}_{2}-\mathrm{CaCl}_{2}-\mathrm{NH}_{3}$ resorption working pair vs. refrigeration and heat source temperatures (a) global conversion rate; (b)sorption quantity.

Fig.4 shows sorption characteristics of resorption working pairs under the condition of $-20^{\circ} \mathrm{C}-5^{\circ} \mathrm{C}$ refrigeration temperature, $30^{\circ} \mathrm{C}-35^{\circ} \mathrm{C}$ heat sink temperature and $150^{\circ} \mathrm{C}$ heat source temperature. For different resorption working pairs, it is demonstrated that sorption quantity of $\mathrm{MnCl}_{2}-\mathrm{CaCl}_{2}-\mathrm{NH}_{3}$ is almost the same with that of $\mathrm{MnCl}_{2}-\mathrm{NH}_{4} \mathrm{Cl}-\mathrm{NH}_{3}$ under the condition of $150^{\circ} \mathrm{C}$ heat source temperature and $30^{\circ} \mathrm{C}$ heat sink temperature. Also worth noting that $\mathrm{MnCl}_{2}-\mathrm{NH}_{4} \mathrm{Cl}-\mathrm{NH}_{3}$ tends to be easily influenced by heat sink temperature. With the increase of heat sink temperature from $30^{\circ} \mathrm{C}-35^{\circ} \mathrm{C}$, sorption quantity of $\mathrm{MnCl}_{2}-\mathrm{NH}_{4} \mathrm{Cl}-\mathrm{NH}_{3}$ drops from the highest to the lowest value among these three resorption working pairs. Fig.5 indicates sorption quantity under the condition of $-20^{\circ} \mathrm{C}-5^{\circ} \mathrm{C}$ refrigeration temperature, $130^{\circ} \mathrm{C}-140^{\circ} \mathrm{C}$ heat source temperature and $30^{\circ} \mathrm{C}$ heat sink temperature. Sorption quantity differences among resorption working pairs will become obvious with the increase of heat source temperature and the decrease of refrigeration temperature. In most cases, $\mathrm{MnCl}_{2}-\mathrm{CaCl}_{2}-\mathrm{NH}_{3}$ shows the best performance among three working pairs. For different heat source temperatures and refrigeration temperatures, sorption quantities of resorption working pairs range from $0.169 \mathrm{~kg} \cdot \mathrm{kg}^{-1}$ to $0.499 \mathrm{~kg} \cdot \mathrm{kg}^{-1}$. 


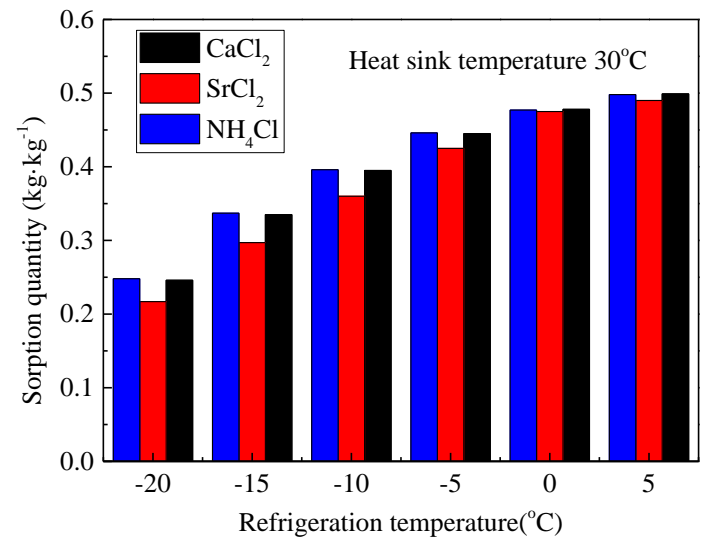

(a)

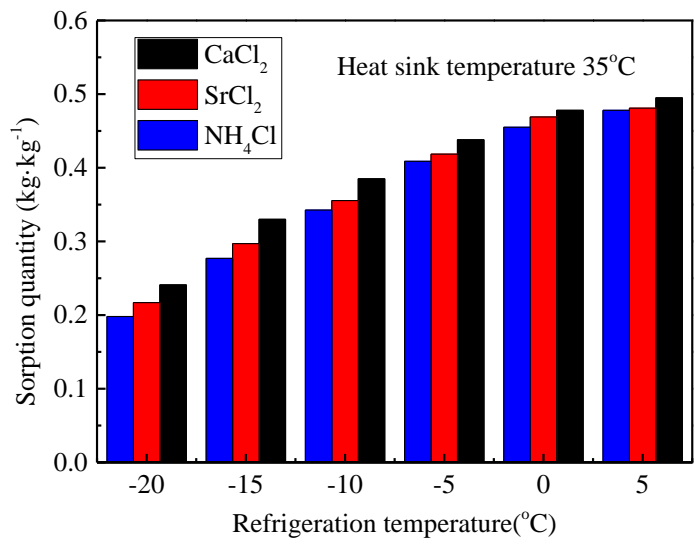

(b)

Fig.4. Sorption characteristic of resorption working pairs vs. refrigeration temperatures (a) $30^{\circ} \mathrm{C}$ heat sink temperature; (b) $35^{\circ} \mathrm{C}$ heat sink temperature.

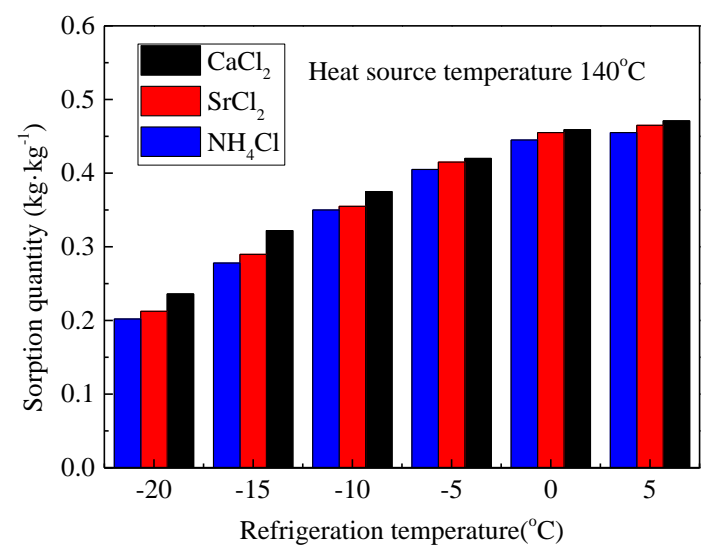

(a)

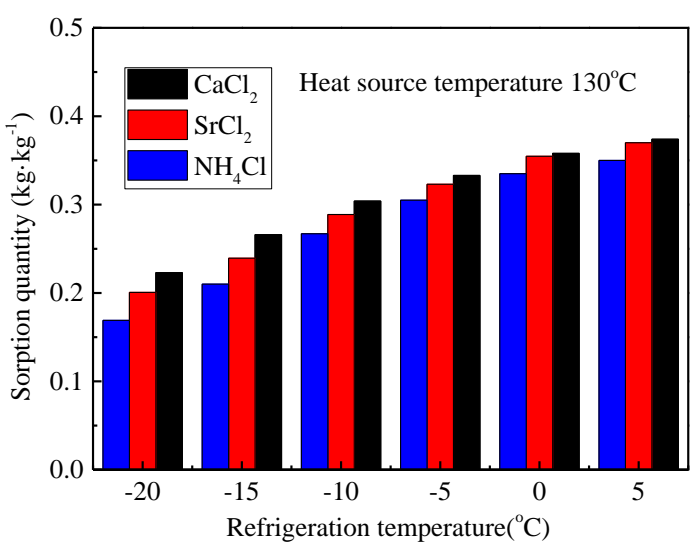

(b)

Fig.5. Sorption characteristic of resorption working pairs vs. refrigeration temperatures (a) $140^{\circ} \mathrm{C}$ heat source temperature; (b) $130^{\circ} \mathrm{C}$ heat source temperature.

Fig.6 indicates global conversion rate and sorption quantity of $\mathrm{MnCl}_{2}-\mathrm{NH}_{3}$ under the condition of refrigeration temperature ranging from $-20^{\circ} \mathrm{C}$ to $5^{\circ} \mathrm{C}$, which is the same with that of resorption working pairs. When global conversion rate equals to 1 , it demonstrates that the reaction proceeds completely. The corresponding maximum equilibrium sorption quantity of $\mathrm{MnCl}_{2}-\mathrm{NH}_{3}$ is $0.54 \mathrm{~kg} \cdot \mathrm{kg}^{-1}$ as shown in Table 1 . Theoretically, when the constraining pressure is away from equilibrium conditions, global conversion rate is bound to reach 1 eventually 
with sufficient reaction duration. Nonetheless, in real sorption process, it is difficult for global conversion rate to reach 1 due to the relatively short duration. The highest global conversion rate and sorption quantity of $\mathrm{MnCl}_{2}$ composite sorbent are able to reach $99 \%$ and $0.536 \mathrm{~kg} \cdot \mathrm{kg}^{-1}$. It could be found that under similar temperature conditions, sorption quantity of $\mathrm{MnCl}_{2}-\mathrm{NH}_{3}$ is higher than that of resorption working pairs when sorption time is the same. This is mainly because pressure difference of $\mathrm{MnCl}_{2}-\mathrm{NH}_{3}$ working pairs between refrigeration and equilibrium temperature is higher than that of resorption pairs. For example, when refrigeration temperature and heat sink temperature are $5^{\circ} \mathrm{C}$ and $30^{\circ} \mathrm{C}$, pressure difference of $\mathrm{MnCl}_{2}-\mathrm{NH}_{3}$ is $0.5 \mathrm{MPa}$, which is 2.5 times higher than that of $\mathrm{MnCl}_{2}-\mathrm{NH}_{4} \mathrm{Cl}-\mathrm{NH}_{3}$ and much higher than that of other two resorption working pairs.

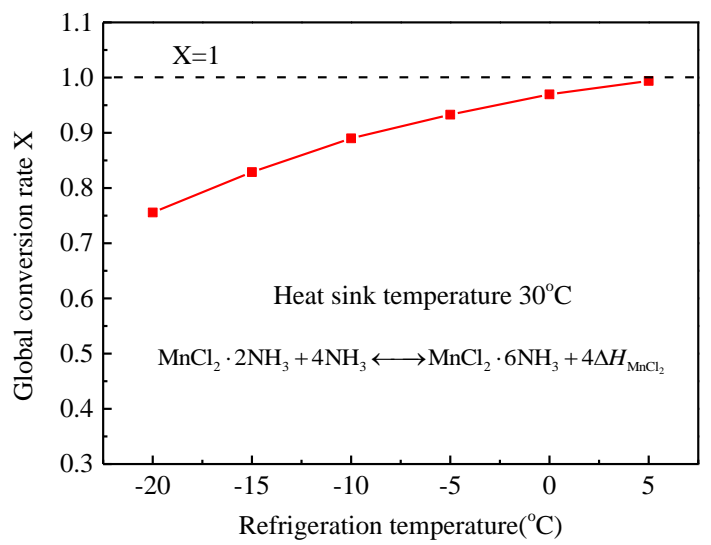

(a)

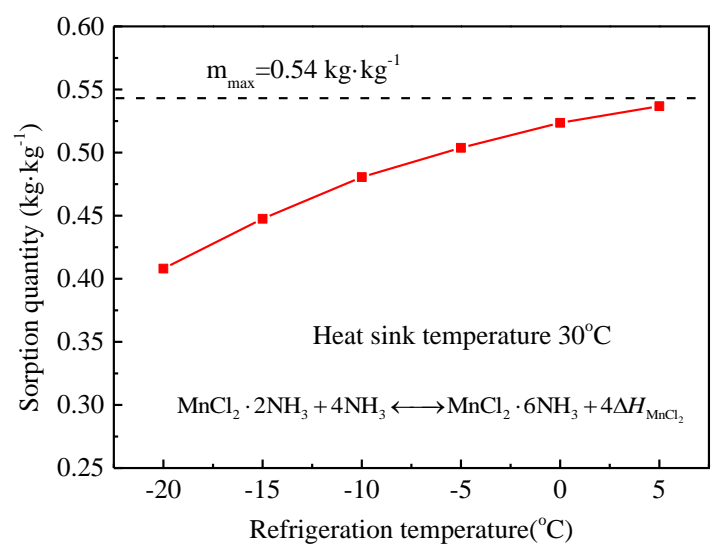

(b)

Fig.6. Sorption characteristics of $\mathrm{MnCl}_{2}-\mathrm{NH}_{3}$ vs. refrigeration temperatures (a) global conversion rate; (b) sorption quantity.

\section{Modular sorption and resorption thermal cell}

\subsection{Concept introduction}

Fig.7 indicates the concept of modular sorption thermal cell. Different from conventional STES system, modular sorption thermal cell integrates sorption reactor, condenser and evaporator into one sorption tank, which is arranged as up and down structure. An insulation layer will be placed in the middle of sorption and resorption thermal cell to avoid mutual heat loss. Two apparatus are connected with a mass channel and a refrigerant valve. 
In the charging process, sorption reactor is heated by external low grade heat. The refrigerant is desorbed from sorption reactor to liquid tank, and then condensed by releasing its condensation heat to environmental heat sink. As liquid tank lies in the up side, it will be conducive to condensing process. After the charging process, refrigerant valve between sorption reactor and liquid tank will be closed to separate sorbent and refrigerant. Thermal energy will be stored and transformed in form of chemical potential. Once heat and cold demands are required, the refrigerant valve between sorption reactor and liquid tank will be open again. During the discharging process, liquid tank will be cooled to refrigeration temperature, and the refrigerant evaporates and flows into sorption reactor for heat and cold supply. Considering liquid tank lies in the low side, it will be conducive to evaporation process. Sorption heat released by the sorbent will provide the heat for end user. Simultaneously, evaporation latent heat of the refrigerant will supply useful cold for end user. It is quite flexible for sorption thermal cell to supply cold and heat separately or cold and heat cogeneration for the user since evaporation heat and sorption heat could supply cold at a low temperature and heat at a high temperature. For modular resorption thermal cell as shown in Fig.8, liquid tank of sorption thermal cell is replaced with LTS reactor for a improved performance of cold output. Charging and discharging processes of modular resorption thermal cell are similar with processes of sorption thermal cell. Function of HTS reactor corresponds to that of the reactor of sorption thermal cell while function of LTS reactor is in accord with that of liquid tank.

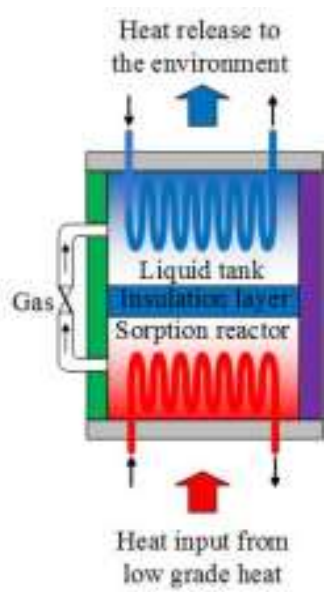

(a)

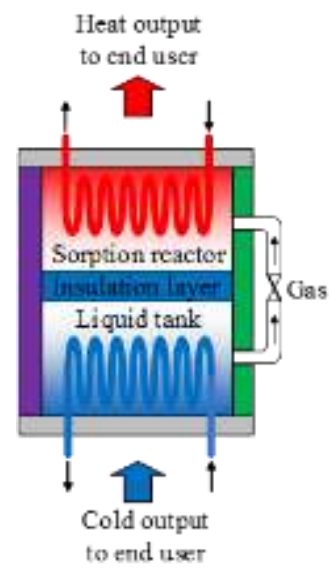

(b)

Fig.7. Concept of modular sorption thermal cell (a) charging process; (b) discharging process. 


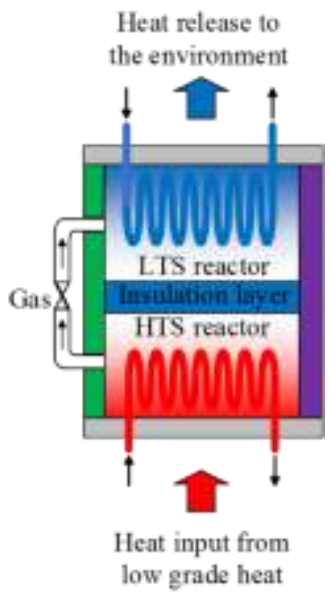

(a)

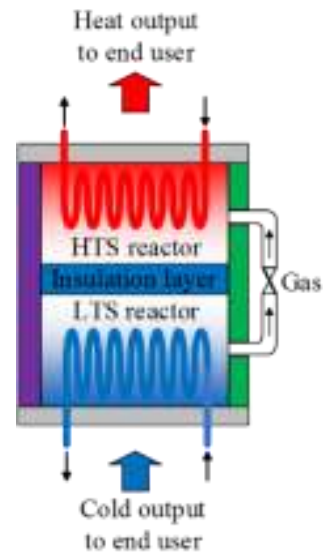

(b)

Fig.8. Concept of modular resorption thermal cell (a) charging process; (b) discharging process.

For sorption working pair, working pressure is determined by working temperature, which can be according to equation 9. Through this monovariant characteristic, modular sorption thermal cell could be easily adapted to external conditions. Fig.9a indicates $P-T$ schematic diagram of modular sorption thermal cell. During the charging process, the sorbent will be heated from point D to point A. Ammonia will be desorbed and flows into liquid tank. Desorption process will proceed from point A to point B. In this process, thermal energy is converted into chemisorption potential by breaking the binding force of sorption working pairs. The constraining temperature should be higher than $T_{\mathrm{in}}$. The higher driving temperature difference is, the faster desorption rate becomes. In the discharging process, evaporator is cooled from point $\mathrm{B}$ to point $\mathrm{C}$ whereas sorption reactor is cooled from point $\mathrm{A}$ to point D. In this case, heat output temperature for heat supply is usually lower than heat input temperature. Ammonia will be evaporated and then be sorbed by sorption reactor. Sorption process will proceed from point $\mathrm{C}$ to point D. In this process, the stable cold and heat output could be obtained by adjusting the temperature of sorption reactor and liquid tank. Cold and heat cogeneration mode is very suitable for long-term energy storage since it demonstrates a good match between energy supply and demand. Similar with modular sorption thermal 
cell, working principle of modular resorption thermal cell is based on resorption working pairs i.e. HTS and LTS which is shown in Fig.9b. HTS has a higher equilibrium pressure than that of LTS in term of the same constraining temperature. During the charging process, ammonia is transferred from HTS reactor to LTS reactor due to pressure difference between two reactors. In the discharging process, desorption heat of LTS at a refrigeration temperature is used to produce useful cold while sorption heat released by HTS is used to supply useful heat for end user.

$$
\operatorname{Ln}\left(P_{\mathrm{eq}}\right)=-\frac{\Delta H_{\mathrm{R}}}{R T_{\mathrm{eq}}}+\frac{\Delta S}{R}
$$

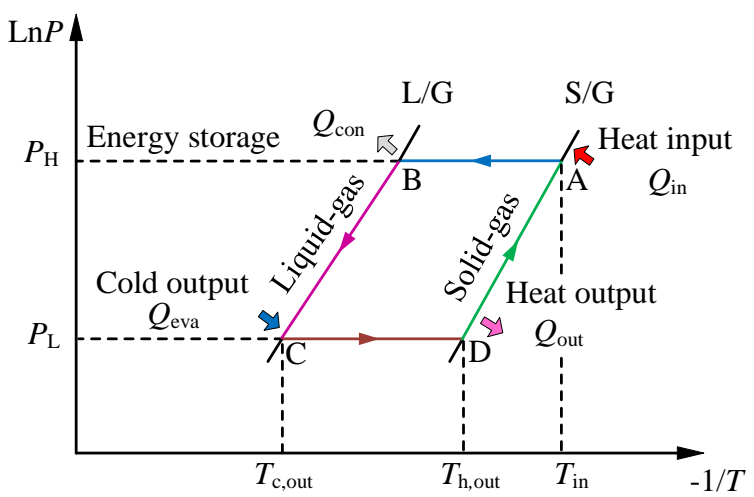

(a)

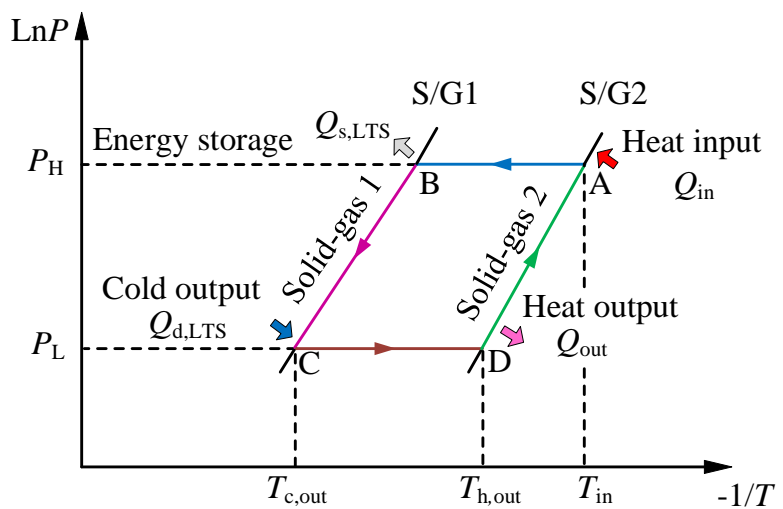

(b)

Fig.9. P-T diagram (a) modular sorption thermal cell; (b) modular resorption thermal cell.

In order to evaluate flexible modes of modular sorption and resorption thermal cell, working pairs of $\mathrm{MnCl}_{2}$ -

$\mathrm{NH}_{3}, \mathrm{MnCl}_{2}-\mathrm{NH}_{4} \mathrm{Cl}-\mathrm{NH}_{3}, \mathrm{MnCl}_{2}-\mathrm{CaCl}_{2}-\mathrm{NH}_{3}$ and $\mathrm{MnCl}_{2}-\mathrm{SrCl}_{2}-\mathrm{NH}_{3}$ are analyzed and compared, which are indicated in Fig.10a, Fig.10b, Fig.10c and Fig 10d. The reaction line of $\mathrm{CaCl}_{2} 4 / 2$ is not displayed in Fig. 10 due to the fact that $\mathrm{CaCl}_{2}$ ammoniate will eventually react with ammonia from 2 moles to 8 moles in selected temperature range.

Fig.10a indicates $P-T$ diagram of sorption thermal cell by using $\mathrm{MnCl}_{2}-\mathrm{NH}_{3}$. As Fig.10a shows, different refrigeration temperatures i.e. $20^{\circ} \mathrm{C}, 5^{\circ} \mathrm{C}$ and $-10^{\circ} \mathrm{C}$ are investigated for further elaboration. $20^{\circ} \mathrm{C}$ is selected for direct heat supply while $5^{\circ} \mathrm{C}$ and $-10^{\circ} \mathrm{C}$ are chosen for cold and heat cogeneration, which are classified to air 
conditioning condition and freezing condition. In the charging process, the sorbent is heated by low grade heat with input temperature of $152^{\circ} \mathrm{C}$. Ammonia will be desorbed and condensed with condensation pressure of 1.15 MPa by releasing condensation heat to heat sink at a temperature of $30^{\circ} \mathrm{C}$. In the discharging process, liquid tank and sorption reactor will mutually connected. Sorption heat released by $\mathrm{MnCl}_{2}$ ammoniates could be used to supply heat for end user and evaporation heat of ammonia can be used to supply cold. For direct heat supply mode, heat could be produced at output temperature of $141^{\circ} \mathrm{C}$ when refrigeration temperature is $20^{\circ} \mathrm{C}$. For cold and heat cogeneration, heat is able to be supplied at temperature of $126^{\circ} \mathrm{C}$ when refrigeration temperature is $5^{\circ} \mathrm{C}$ for air conditioning condition. Cold could be supplied in freezing condition at temperature of $-10^{\circ} \mathrm{C}$ whereas heat output temperature is $110^{\circ} \mathrm{C}$. Due to the monovariant characteristic of sorption process, equilibrium temperature for cold output corresponds to equilibrium temperature for heat output. Thus, modular sorption thermal cell has a distinct capability of producing different cold and heat output temperatures during the discharging process. Although modular resorption thermal cell has similar working principle with that of sorption thermal cell, it usually has the lower heat input and output temperature under the condition of same heat sink temperature and refrigeration temperature due to resorption characteristics, which are shown in Fig.10b, Fig10c and Fig.10d. Compared with $\mathrm{MnCl}_{2}-\mathrm{NH}_{3}$, heat input temperature for $\mathrm{MnCl}_{2}-\mathrm{NH}_{4} \mathrm{Cl}-\mathrm{NH}_{3}, \mathrm{MnCl}_{2}-\mathrm{CaCl}_{2}-\mathrm{NH}_{3}$ and $\mathrm{MnCl}_{2}-\mathrm{SrCl}_{2}-\mathrm{NH}_{3}$ decreases from $152^{\circ} \mathrm{C}$ to $127^{\circ} \mathrm{C}, 85^{\circ} \mathrm{C}$ and $75^{\circ} \mathrm{C}$. Simultaneously for direct heat supply mode, heat output temperature decreases from $141^{\circ} \mathrm{C}$ to $117^{\circ} \mathrm{C}, 70^{\circ} \mathrm{C}$ and $66^{\circ} \mathrm{C}$. With regard to cold and heat cogeneration, the output temperature also decreases from $126^{\circ} \mathrm{C}$ to $101^{\circ} \mathrm{C}, 55^{\circ} \mathrm{C}$ and $45^{\circ} \mathrm{C}$ when refrigeration temperature is $5^{\circ} \mathrm{C}$ for LTS. 


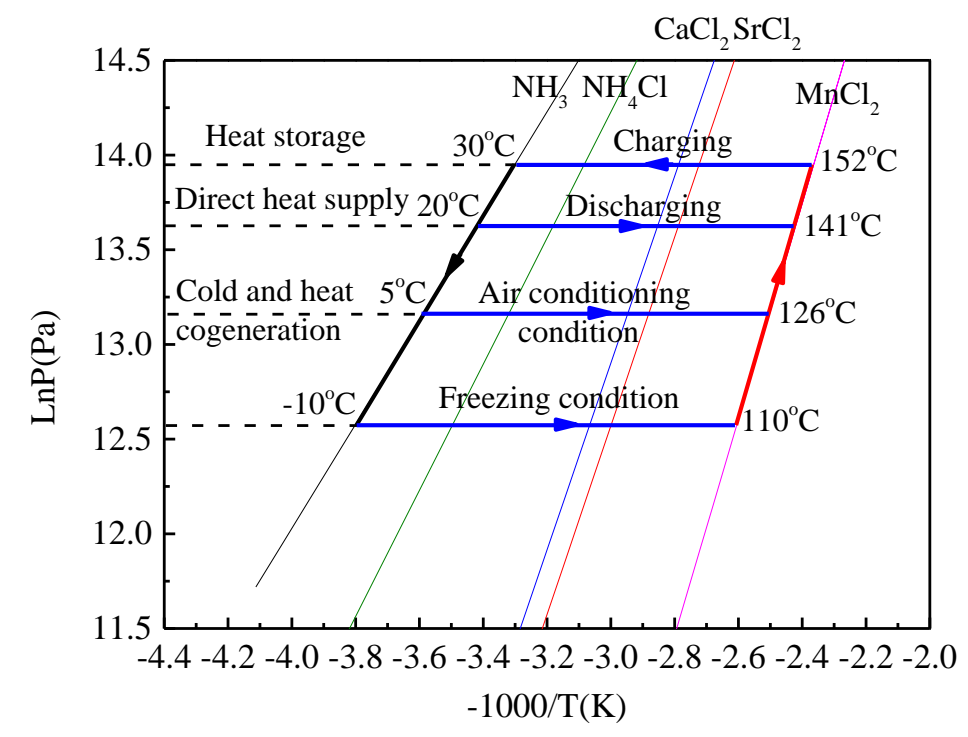

(a)

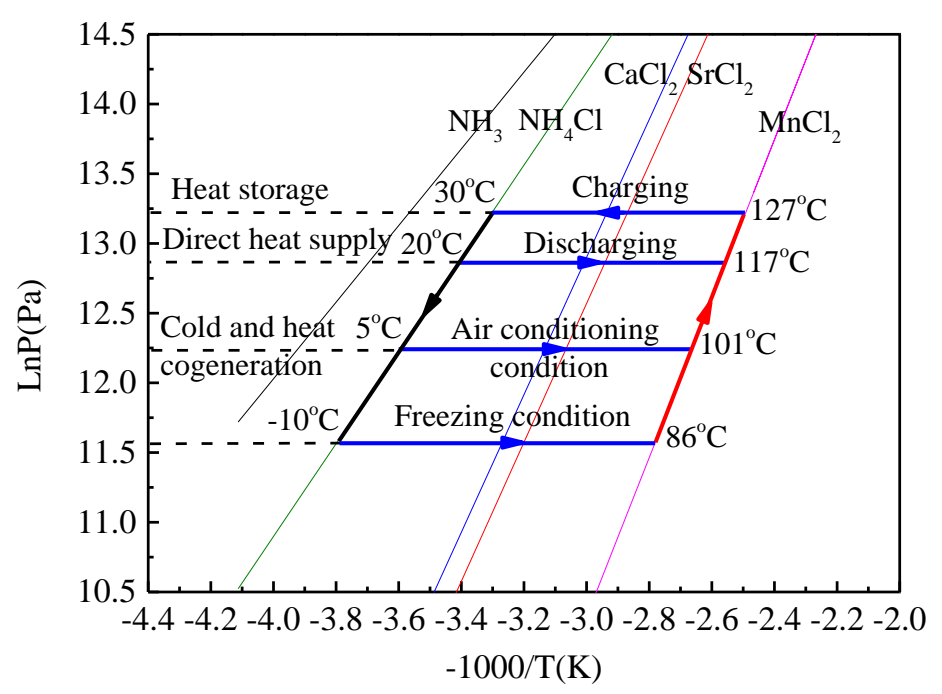

(b)

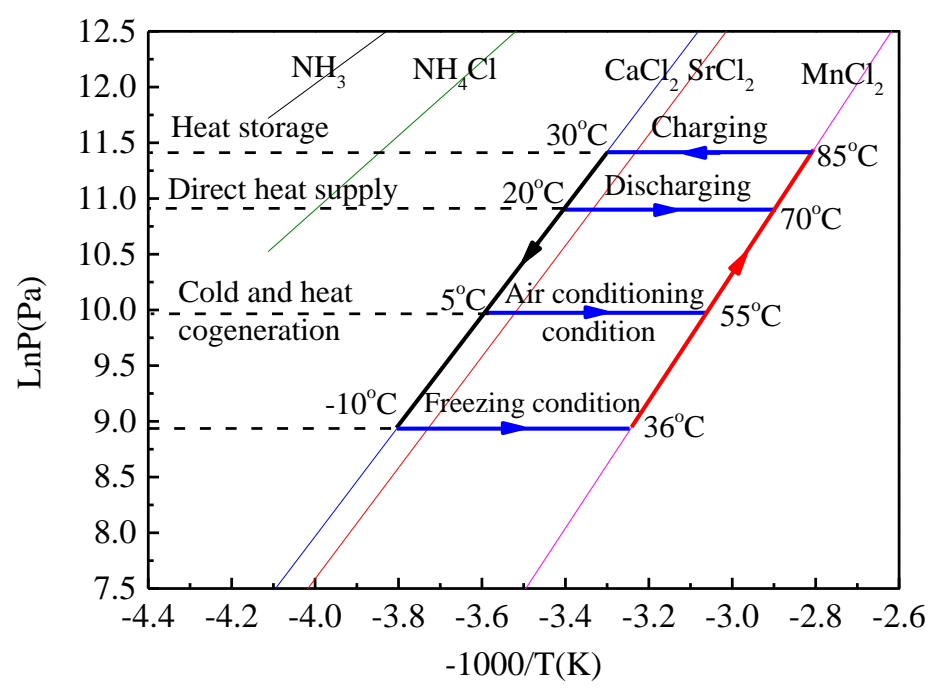

(c) 


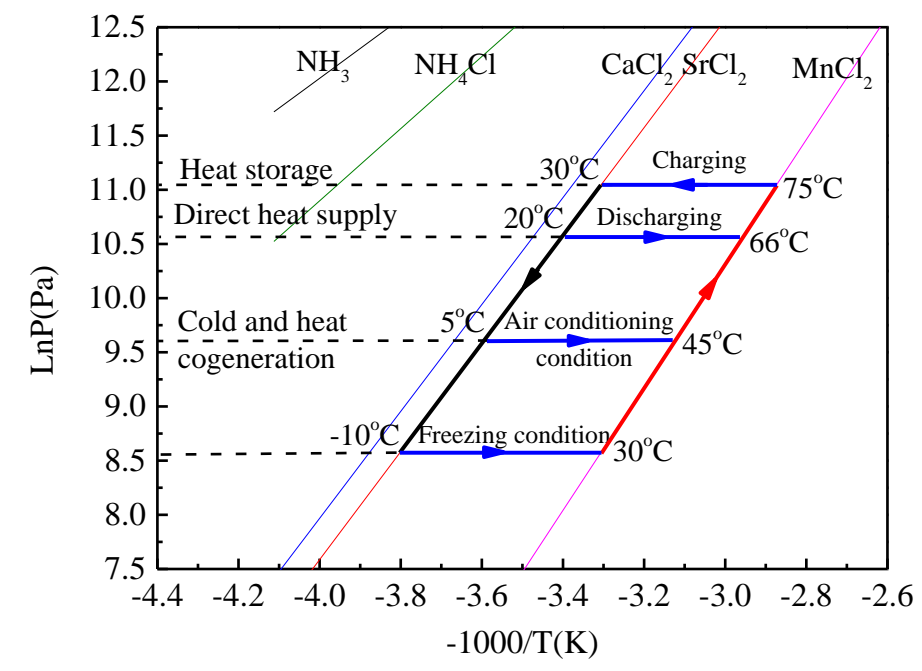

(d)

Fig.10. P-T diagram of modular sorption and resorption thermal cell for cold and heat cogeneration vs. working pairs (a) $\mathrm{MnCl}_{2}-\mathrm{NH}_{3}$; (b) $\mathrm{MnCl}_{2}-\mathrm{NH}_{4} \mathrm{Cl}-\mathrm{NH}_{3}$; (c) $\mathrm{MnCl}_{2}-\mathrm{CaCl}_{2}-\mathrm{NH}_{3}$; (d) $\mathrm{MnCl}_{2}-\mathrm{SrCl}_{2}-\mathrm{NH}_{3}$.

\subsection{Evaluation of modular sorption and resorption thermal cell}

In order to have an overall comparison between modular sorption and resorption thermal cell, $1 \mathrm{~kg}$ HTS composite sorbent is taken as the reference for evaluating the performance. Heat output of modular sorption and resorption thermal cell in the discharging process can be expressed as equations 10 and 11:

$$
Q_{\mathrm{h}, \text { out } 1}=Q_{\mathrm{s}} \pm Q_{\text {reactor }}
$$

where $Q_{\mathrm{s}}$ is reaction heat, $Q_{\text {reactor }}$ is sensible heat consumed by sorption reactor which includes sensible heat of composite sorbent and metal part of sorption reactor.

$$
Q_{\mathrm{h}, \text { out } 2}=Q_{\mathrm{HTS}} \pm Q_{\text {reactor,HTS }}
$$

where $Q_{\text {HTS }}$ is reaction heat of HTS, $Q_{\text {reactor }}$ is sensible heat consumed by HTS reactor which includes sensible heat of HTS composite sorbent and metal part of HTS reactor. Sensible heat will take a positive or negative effect which is determined by different working conditions i.e. short-term or long-term energy storage.

Cold output of modular sorption and resorption thermal cell in the discharging process could be expressed as equations 12 and 13: 


$$
Q_{\mathrm{c}, \text { out } 1}=Q_{\mathrm{eva}}-Q_{\text {evaporator }}
$$

where $Q_{\text {eva }}$ is evaporation heat of ammonia, $Q_{\text {evaporator }}$ is sensible heat consumed by the evaporator when it is cooled from environmental temperature to refrigeration temperature, which is composed of the sensible heat of ammonia and metal part of the evaporator.

$$
Q_{\text {c,out } 2}=Q_{\mathrm{LTS}}-Q_{\text {reactor, } \mathrm{LTS}}
$$

where $Q_{\text {LTS }}$ is reaction heat of LTS, $Q_{\text {reactor, LTS }}$ is sensible heat consumed by LTS reactor when it is cooled from environmental temperature to refrigeration temperature, which is composed of sensible heat of LTS composite sorbent and metal part of LTS reactor.

Energy storage density, which is defined as the amount of energy output based on mass of sorbent, is used to assess the performance of modular sorption and resorption thermal cell for cold and heat cogeneration. Heat and cold density for sorption and resorption thermal cell could be expressed as equations 14 and 15 as well as 16 and 17 , respectively.

Heat density for modular sorption thermal cell:

$$
H D_{\mathrm{s}}=\frac{Q_{\mathrm{h}, \text { out } 1}}{M_{\mathrm{sor}}}
$$

Heat density for modular resorption thermal cell:

$$
H D_{\text {res }}=\frac{Q_{\mathrm{h}, \text { out } 2}}{M_{\mathrm{HTS}}}
$$

Cold density for modular sorption thermal cell:

$$
C D_{\mathrm{s}}=\frac{Q_{\mathrm{c}, \mathrm{out} 1}}{M_{\mathrm{sor}}}
$$

Cold density for modular resorption thermal cell:

$$
C D_{\text {res }}=\frac{Q_{\text {c,out } 2}}{M_{\mathrm{HTS}}}
$$


where $M_{\text {sor }}$ and $M_{\mathrm{HTS}}$ is mass of composite sorbents i.e. composite $\mathrm{MnCl}_{2}$.

Power density, which is defined as the amount of power output based on mass of sorbent, is also used to evaluate the performance of modular sorption and resorption thermal cell for cold and heat cogeneration. Heat and cold power density for sorption and resorption thermal cell could be expressed as equations 18 and 19 as well as 20 and 21 , respectively.

Heat power density for modular sorption thermal cell:

$$
P D_{\mathrm{h}, \mathrm{s}}=\frac{Q_{\mathrm{h}, \text { out } 1}}{t_{\mathrm{s}} \cdot M_{\mathrm{sor}}}
$$

Heat power density for modular resorption thermal cell:

$$
P D_{\mathrm{h}, \mathrm{res}}=\frac{Q_{\mathrm{h}, \text { out } 2}}{t_{\mathrm{s}} \cdot M_{\mathrm{HTS}}}
$$

Cold power density for modular sorption thermal cell:

$$
P D_{\mathrm{c}, \mathrm{s}}=\frac{Q_{\mathrm{c}, \mathrm{out} 1}}{t_{\mathrm{s}} \cdot M_{\mathrm{sor}}}
$$

Cold power density for modular resorption thermal cell:

$$
P D_{\mathrm{c}, \mathrm{res}}=\frac{Q_{\mathrm{c}, \mathrm{out} 1}}{t_{\mathrm{s}} \cdot M_{\mathrm{HTS}}}
$$

where $t_{\mathrm{s}}$ is sorption time.

\subsection{Performance analysis}

Theoretical energy density and equilibrium desorption temperature of modular sorption and resorption thermal cell are analyzed in term of sorption and resorption working pairs, which are shown in Fig.11. Fig.11a and Fig.11b indicate heat and cold density, respectively. With regard to heat density, one striking fact is that resorption working pairs have the same theoretical performance with that of sorption working pair based on same HTS. The advantage of resorption working pairs for heat supply lies in lower desorption temperature and no liquid ammonia in the system. The highest theoretical heat density could reach $2178 \mathrm{~kJ} \cdot \mathrm{kg}^{-1}$ for working pairs of $\mathrm{CaCl}_{2}-\mathrm{NH}_{4} \mathrm{Cl}-$ 
$\mathrm{NH}_{3}$ and $\mathrm{CaCl}_{2}-\mathrm{NH}_{3}$ due to the fact that $\mathrm{CaCl}_{2}$ proceeds two reaction processes of $\mathrm{CaCl}_{2} 8 / 4$ and $\mathrm{CaCl}_{2} 4 / 2$ in selected operating temperature which results in double sorption heat output. For different working pairs, theoretical heat density ranges from $1443 \mathrm{~kJ} \cdot \mathrm{kg}^{-1}$ to $2178 \mathrm{~kJ} \cdot \mathrm{kg}^{-1}$.

For cold density, resorption working pairs demonstrate the better performance than that of sorption working pair by using same HTS. It is indicated that the highest cold density is able to reach $1480.5 \mathrm{~kJ}^{\mathrm{kg}} \mathrm{kg}^{-1}$ by using working pair of $\mathrm{CaCl}_{2}-\mathrm{NH}_{4} \mathrm{Cl}-\mathrm{NH}_{3}$. For different working pairs, theoretical cold density ranges from $630 \mathrm{~kJ} \cdot \mathrm{kg}^{-1}$ to $1480.5 \mathrm{~kJ} \cdot \mathrm{kg}^{-1}$. Nonetheless, $\mathrm{CaCl}_{2}-\mathrm{NH}_{4} \mathrm{Cl}-\mathrm{NH}_{3}$ is not suitable for cold and heat cogeneration mode when the cold is required for freezing condition. This is mainly because that heat output temperature of $\mathrm{CaCl}_{2}-\mathrm{NH}_{4} \mathrm{Cl}-\mathrm{NH}_{3}$ will be quite low when cold output temperature is in freezing condition. Therefore, $\mathrm{MnCl}_{2}$ is selected as HTS for further analysis based on testing results, which is more flexible for cold and heat cogeneration.

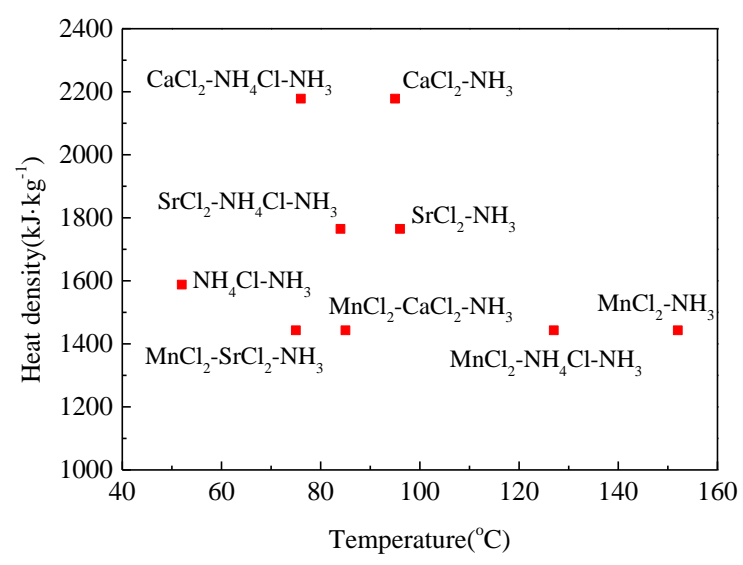

(a)

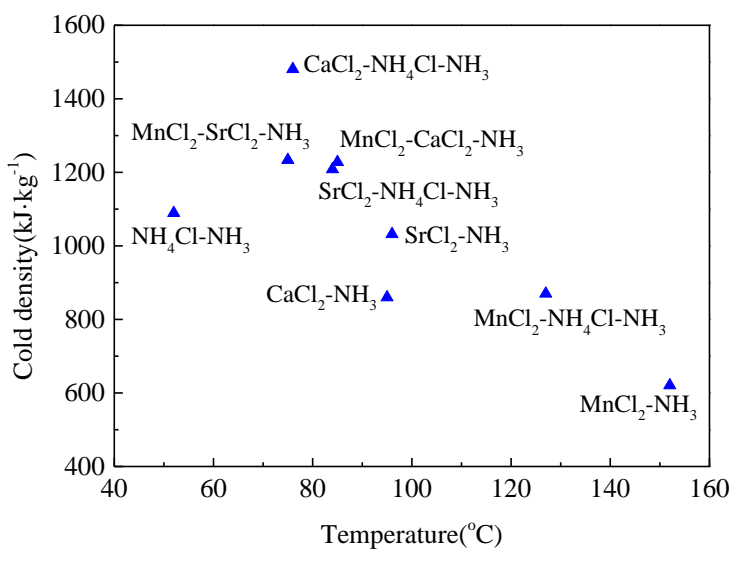

(b)

Fig.11. Theoretical cold and heat density of modular sorption and resorption thermal cell vs. equilibrium desorption temperatures (a) heat density (b) cold density.

Based on sorption and resorption characteristics, performance of modular sorption and resorption thermal cell are analyzed and compared. For evaluating energy storage density and power density, sensible heat will not be considered since sensible heat could be utilized for short term energy storage whereas it cannot be applied for 
seasonal energy storage. Reaction heat will be relatively stable for both short term and long term energy storage. Since resorption working pairs reveal similar trends for energy density and power density, $\mathrm{MnCl}_{2}-\mathrm{CaCl}_{2}-\mathrm{NH}_{3}$ working pair is selected as an example for further illustration. Fig.12 shows heat and cold density under the condition of $-20^{\circ} \mathrm{C}$ to $5^{\circ} \mathrm{C}$ refrigeration temperature. It is worth noting that both heat and cold density increase with the increase of refrigeration temperature when heat source temperature and heat sink temperature are $150^{\circ} \mathrm{C}$ and $30^{\circ} \mathrm{C}$. The highest heat and cold density could reach $1333 \mathrm{~kJ} \cdot \mathrm{kg}^{-1}$ and $1134 \mathrm{~kJ} \cdot \mathrm{kg}^{-1}$ when refrigeration temperature is $5^{\circ} \mathrm{C}$. For refrigeration temperature ranging from $-20^{\circ} \mathrm{C}$ to $5^{\circ} \mathrm{C}$, heat and cold density of $\mathrm{MnCl}_{2}-\mathrm{CaCl}_{2}-\mathrm{NH}_{3}$ range from $657 \mathrm{~kJ} \cdot \mathrm{kg}^{-1}$ to $1333 \mathrm{~kJ} \cdot \mathrm{kg}^{-1}$ and $559 \mathrm{~kJ} \cdot \mathrm{kg}^{-1}$ to $1134 \mathrm{~kJ} \cdot \mathrm{kg}^{-1}$. Also noting that heat density is higher than cold density at the same refrigeration temperature. This is mainly because that heat is produced by sorption heat of HTS which is usually higher than desorption heat of LTS for cold production. Heat and cold density increase more obviously in freezing condition than that in air conditioning condition. Fig. 13 shows heat and cold power density of modular resorption thermal cell. Sorption time is evaluated when sorption quantity doesn't change by more than $5 \%$ in the rest of sorption process. For evaporation temperature from $-20^{\circ} \mathrm{C}$ to $5^{\circ} \mathrm{C}$, sorption time is in the range from $20 \mathrm{~min}$ to $30 \mathrm{~min}$. It is indicated that heat and cold power density increase with the increase of refrigeration temperature which is similar with that of energy storage density. Energy power density shows the larger variation than energy density. This is mainly because sorption time decreases with the increment of refrigeration temperature. For refrigeration temperature ranging from $-20^{\circ} \mathrm{C}$ to $5^{\circ} \mathrm{C}$, heat and cold power density of $\mathrm{MnCl}_{2}$ $\mathrm{CaCl}_{2}-\mathrm{NH}_{3}$ range from $365 \mathrm{~W} \cdot \mathrm{kg}^{-1}$ to $1111 \mathrm{~W} \cdot \mathrm{kg}^{-1}$ and from $311 \mathrm{~W} \cdot \mathrm{kg}^{-1}$ to $946 \mathrm{~W} \cdot \mathrm{kg}^{-1}$. 


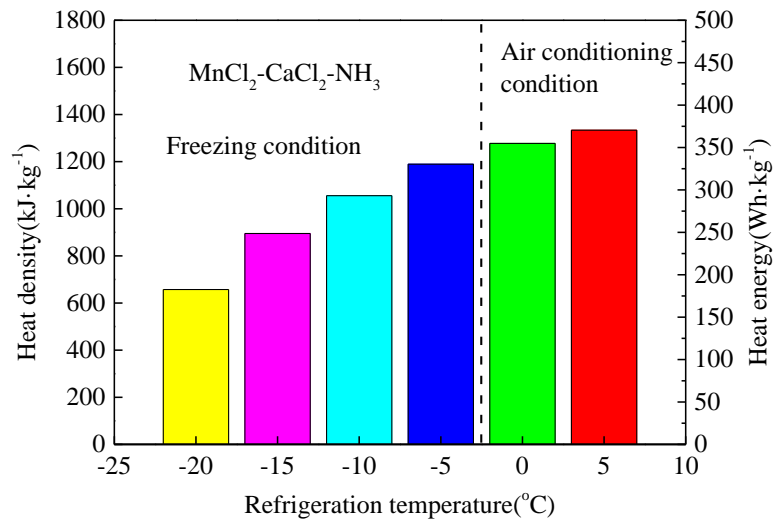

(a)

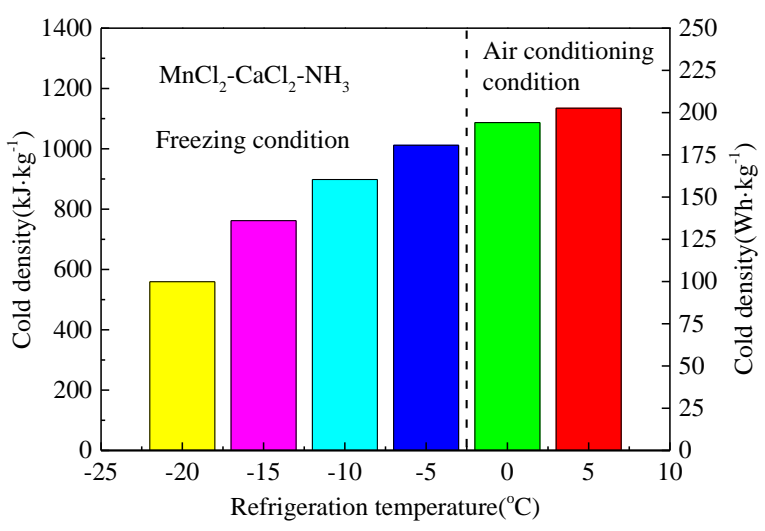

(b)

Fig.12. Energy storage density of resorption thermal cell vs. refrigeration temperatures (a) heat density (b) cold density.

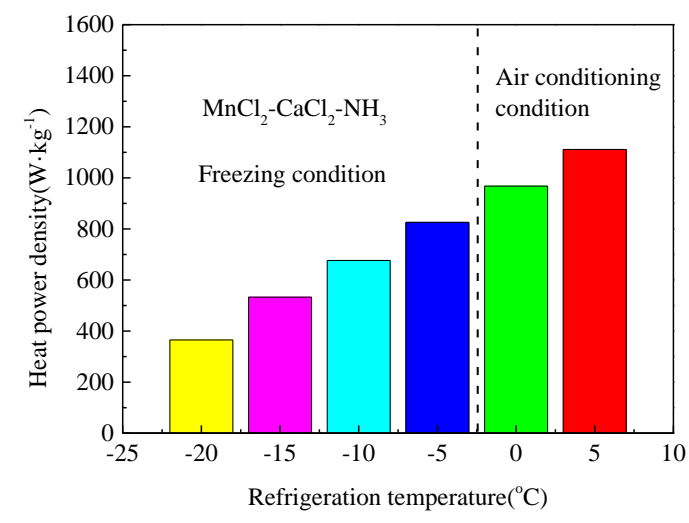

(a)

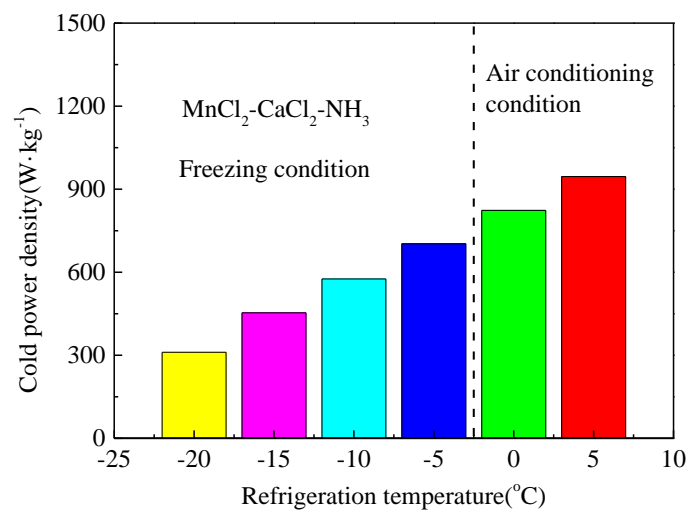

(b)

Fig.13. Energy power density of resorption thermal cell vs. refrigeration temperatures (a) heat power density; (b) cold power density.

Fig.14 shows heat and cold density of sorption and resorption working pairs under the condition of $-20^{\circ} \mathrm{C}$ -

$5^{\circ} \mathrm{C}$ refrigeration temperature. With respect to heat density, $\mathrm{MnCl}_{2}-\mathrm{NH}_{3}$ displays the best performance among sorption and resorption working pairs due to its same sorption heat and higher sorption quantity. $\mathrm{MnCl}_{2}-\mathrm{CaCl}_{2}-$

$\mathrm{NH}_{3}$ has a similar performance with that of $\mathrm{MnCl}_{2}-\mathrm{NH}_{4} \mathrm{Cl}-\mathrm{NH}_{3} \cdot \mathrm{MnCl}_{2}-\mathrm{SrCl}_{2}-\mathrm{NH}_{3}$ shows the lowest heat density.

As for cold density, $\mathrm{MnCl}_{2}-\mathrm{NH}_{3}$ almost has the lowest performance due to the fact that evaporation latent heat of the refrigerant is usually lower than reaction heat of sorbents. It is worth noting that resorption thermal cell is more 
suitable for cold output, and $\mathrm{MnCl}_{2}-\mathrm{CaCl}_{2}-\mathrm{NH}_{3}$ shows the best cold density. For different working pairs, heat density ranges from $580 \mathrm{~kJ} \cdot \mathrm{kg}^{-1}$ to $1368 \mathrm{~kJ} \cdot \mathrm{kg}^{-1}$ whereas cold density ranges from $400 \mathrm{~kJ} \cdot \mathrm{kg}^{-1}$ to $1134 \mathrm{~kJ} \cdot \mathrm{kg}^{-1}$. Fig.15 shows heat and cold power density of sorption and resorption working pairs. One remarkable fact is that heat and cold power density almost show linear variation trends. With regard to heat power density, $\mathrm{MnCl}_{2}-\mathrm{NH}_{3}$ also has the best performance while $\mathrm{MnCl}_{2}-\mathrm{SrCl}_{2}-\mathrm{NH}_{3}$ shows the worst results. It is demonstrated that $\mathrm{MnCl}_{2}$ $\mathrm{CaCl}_{2}-\mathrm{NH}_{3}$ shows the optimal cold power density whereas $\mathrm{MnCl}_{2}-\mathrm{NH}_{4} \mathrm{Cl}-\mathrm{NH}_{3}$ reveals the worst results rather than $\mathrm{MnCl}_{2}-\mathrm{NH}_{3}$. This is mainly because reaction heat of $\mathrm{NH}_{4} \mathrm{Cl}$ is just a little higher than evaporation latent heat of refrigerant. The larger sorption quantity and less sorption time result in higher cold power density. Also worth noting that resorption thermal cell is not always the better choice than sorption thermal cell for cold output. For different working pairs, heat power density ranges from $322 \mathrm{~W} \cdot \mathrm{kg}^{-1}$ to $1502 \mathrm{~W} \cdot \mathrm{kg}^{-1}$ whereas cold power density ranges from $222 \mathrm{~W} \cdot \mathrm{kg}^{-1}$ to $946 \mathrm{~W} \cdot \mathrm{kg}^{-1}$.

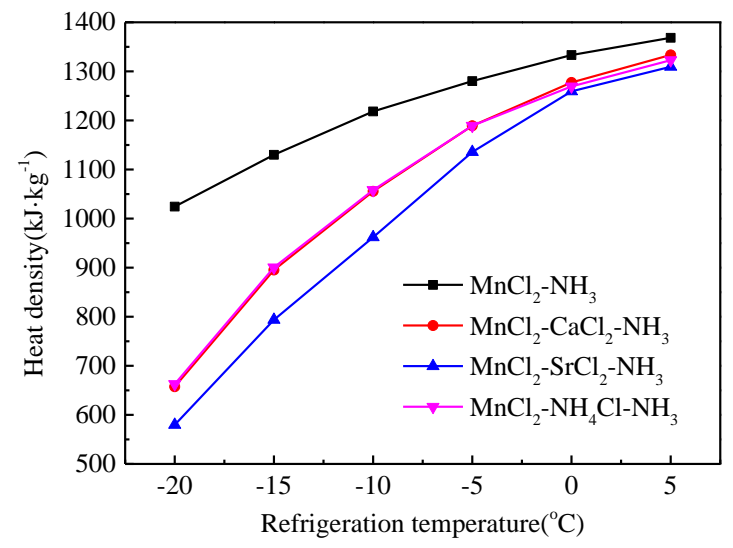

(a)

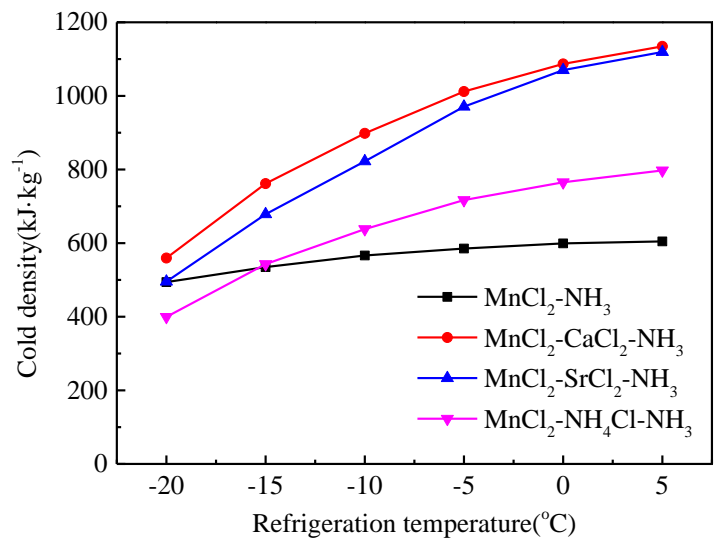

(b)

Fig.14. Energy density of modular sorption and resorption thermal cell vs. working pairs (a) heat density; (b) cold density. 


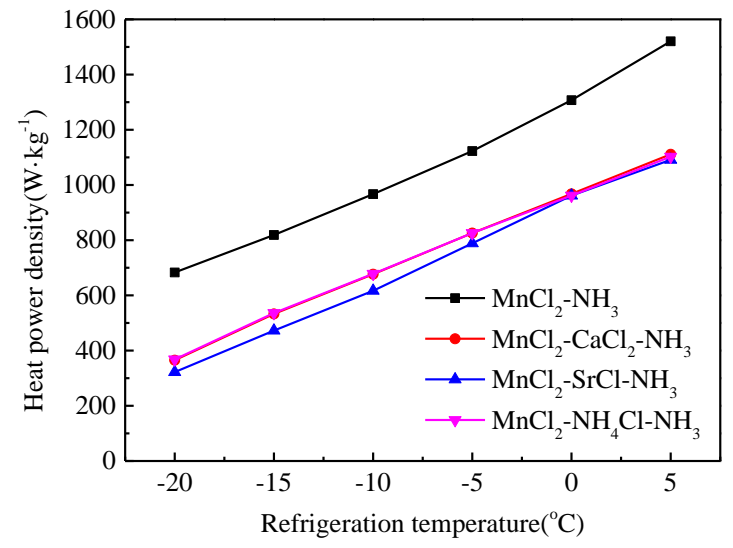

(a)

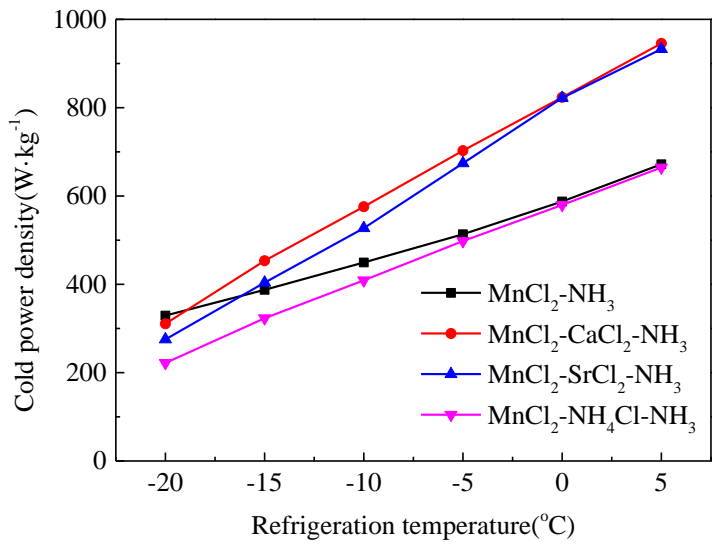

(b)

Fig.15. Energy power density of modular sorption and resorption thermal cell vs. working pairs (a) heat power density; (b) cold power density.

Since both sorption and resorption thermal cell act as modular unit, it means that scaling applications could be accomplished by the combination of this separated unit. Methods for combining electric cell are usually classified to two aspects i.e. series and parallel connections. Since analogy is used between electricity and heat, these two connection methods could also be utilized for both modular sorption and resorption thermal cell. Voltage and current of electric cell are compared to temperature difference and thermal energy. For series connections of modular sorption and resorption thermal cell, temperature difference will be increased by connecting outlet of modular unit to next inlet. Sorbents with gradient equilibrium reaction temperatures will be used in different modular units. During the charging process, heat source with higher temperature will drive the sorbent from the highest equilibrium temperature to the lowest temperature. Series connections are suitable for the place with sufficient variable heat source such as solar power. Considering parallel connections, input and output thermal energy will be increased with a certain temperature difference by parallel connecting separated inlets and outlets. Sorbents with the same equilibrium reaction temperature will be selected, and output heat and cold will be increased with the increment of modular sorption and resorption thermal cell. Both sorption and resorption thermal 
cells should be selected and utilized for overall considering the requirements of demand and supply.

\section{Conclusions}

In order to analyze the performance of novel modular sorption and resorption thermal cell, heat and mass transfer performance as well as sorption characteristic of different working pairs are investigated. ENG-TSA are integrated as the matrix for heat and mass transfer intensification. Conclusions are yielded as follows:

[1] Thermal conductivity increases with the decrease of mass ratio of salt. The highest thermal conductivity of composite sorbents could reach $34.9 \mathrm{~W} \cdot \mathrm{m}^{-1} \cdot \mathrm{K}^{-1}$ for $50 \%$ mass ratio of $\mathrm{NH}_{4} \mathrm{Cl}$, which is about 100 times higher than that of granular $\mathrm{NH}_{4} \mathrm{Cl}$. For different composite sorbents, thermal conductivity ranges from $11.9 \mathrm{~W} \cdot \mathrm{m}^{-1} \cdot \mathrm{K}^{-1}$ to $36.5 \mathrm{~W} \cdot \mathrm{m}^{-1} \cdot \mathrm{K}^{-1}$. Permeability increases with the increase of mass ratio of salt, which ranges from $1.04 \times 10^{-14} \mathrm{~m}^{2}$ to $8.02 \times 10^{-11} \mathrm{~m}^{2}$.

[2] For resorption working pairs, it is demonstrated that sorption quantity of $\mathrm{MnCl}_{2}-\mathrm{CaCl}_{2}-\mathrm{NH}_{3}$ is almost the same with that of $\mathrm{MnCl}_{2}-\mathrm{NH}_{4} \mathrm{Cl}-\mathrm{NH}_{3}$ under the condition of $150^{\circ} \mathrm{C}$ heat source temperature and $30^{\circ} \mathrm{C}$ heat sink temperature. With the increase of heat sink temperature from $30^{\circ} \mathrm{C}$ to $35^{\circ} \mathrm{C}$, sorption quantity of $\mathrm{MnCl}_{2}-\mathrm{NH}_{4} \mathrm{Cl}-\mathrm{NH}_{3}$ drops from the highest to the lowest among resorption working pairs. Under the condition of $-20^{\circ} \mathrm{C}-5^{\circ} \mathrm{C}$ refrigeration temperature and $130^{\circ} \mathrm{C}-140^{\circ} \mathrm{C}$ heat source temperature, sorption quantities of resorption working pairs range from $0.169 \mathrm{~kg} \cdot \mathrm{kg}^{-1}$ to $0.499 \mathrm{~kg} \cdot \mathrm{kg}^{-1}$.

[3] Resorption thermal cell is more suitable for cold output, and working pair of $\mathrm{MnCl}_{2}-\mathrm{CaCl}_{2}-\mathrm{NH}_{3}$ shows the best performance. For sorption and resorption working pairs, heat density ranges from $580 \mathrm{~kJ} \cdot \mathrm{kg}^{-1}$ to $1368 \mathrm{~kJ} \cdot \mathrm{kg}^{-1}$ whereas cold density ranges from $400 \mathrm{~kJ} \cdot \mathrm{kg}^{-1}$ to $1134 \mathrm{~kJ} \cdot \mathrm{kg}^{-1}$. For heat power density, $\mathrm{MnCl}_{2}-\mathrm{NH}_{3}$ has the best performance while $\mathrm{MnCl}_{2}-\mathrm{SrCl}_{2}-\mathrm{NH}_{3}$ shows the worst results. For cold power density $\mathrm{MnCl}_{2}-\mathrm{NH}_{4} \mathrm{Cl}-\mathrm{NH}_{3}$ reveals the worst results rather than $\mathrm{MnCl}_{2}-\mathrm{NH}_{3}$. For different working pairs, heat power density ranges from $322 \mathrm{~W} \cdot \mathrm{kg}^{-1}$ to $1502 \mathrm{~W} \cdot \mathrm{kg}^{-1}$ whereas cold power density ranges from 
$222 \mathrm{~W} \cdot \mathrm{kg}^{-1}$ to $946 \mathrm{~W} \cdot \mathrm{kg}^{-1}$.

[4] For scaling applications of modular sorption and resorption thermal cell, series connections and parallel connections will be adopted. The former is conducive to the adjustment for variable heat source, and large heat and cold temperature slide could be obtained. The latter will further increase the quantity of heat and cold output with the increment of modular sorption and resorption thermal cell.

\section{Acknowledgements}

This research was supported by the National Natural Science Foundation of China under contract number (51606118), Innovative Research Groups under contract number (51521004) and Heat-STRESS project (EP/N02155X/1) funded by the Engineering and Physical Science Research Council of the UK.

\section{References}

[1] Roskilly AP, Taylor PC, Yan J. Energy storage systems for a low carbon future - in need of an integrated approach. Applied Energy. 2015;137:463-6.

[2] Freni A, Sapienza A, Glaznev IS, Aristov YI, Restuccia G. Experimental testing of a lab-scale adsorption chiller using a novel selective water sorbent "silica modified by calcium nitrate". International Journal of Refrigeration. 2012;35(3):518-24.

[3] Myers Jr PD, Goswami DY. Thermal energy storage using chloride salts and their eutectics. Applied Thermal Engineering. 2016;109, Part B:889-900.

[4] Baeten B, Rogiers F, Helsen L. Reduction of heat pump induced peak electricity use and required generation capacity through thermal energy storage and demand response. Applied Energy. 2017;195:184-95.

[5] Wu M, Li M, Xu C, He Y, Tao W. The impact of concrete structure on the thermal performance of the dualmedia thermocline thermal storage tank using concrete as the solid medium. Applied Energy. 2014;113:1363-71. 
[6] Mawire A, Taole SH. A comparison of experimental thermal stratification parameters for an oil/pebble-bed thermal energy storage (TES) system during charging. Applied Energy. 2011;88(12):4766-78.

[7] Nunes VMB, Queirós CS, Lourenço MJV, Santos FJV, Nieto de Castro CA. Molten salts as engineering fluids - A review: Part I. Molten alkali nitrates. Applied Energy. 2016;183:603-11.

[8] Kuravi S, Trahan J, Goswami DY, Rahman MM, Stefanakos EK. Thermal energy storage technologies and systems for concentrating solar power plants. Progress in Energy and Combustion Science. 2013;39(4):285-319.

[9] Zhang P, Meng ZN, Zhu H, Wang YL, Peng SP. Melting heat transfer characteristics of a composite phase change material fabricated by paraffin and metal foam. Applied Energy. 2017;185, Part 2:1971-83.

[10] Milián YE, Gutiérrez A, Grágeda M, Ushak S. A review on encapsulation techniques for inorganic phase change materials and the influence on their thermophysical properties. Renewable and Sustainable Energy Reviews. 2017;73:983-99.

[11] Esen M, Ayhan T. Development of a model compatible with solar assisted cylindrical energy storage tank and variation of stored energy with time for different phase change materials. Energy Conversion and Management. 1996;37(12):1775-85.

[12] Mao Q. Recent developments in geometrical configurations of thermal energy storage for concentrating solar power plant. Renewable and Sustainable Energy Reviews. 2016;59:320-7.

[13] Jiang L, Gao J, Wang L, Wang R, Lu Y, Roskilly AP. Investigation on performance of multi-salt composite sorbents for multilevel sorption thermal energy storage. Applied Energy. 2017;190:1029-38.

[14] Elsayed A, Elsayed E, Al-Dadah R, Mahmoud S, Elshaer A, Kaialy W. Thermal energy storage using metalorganic framework materials. Applied Energy. 2017;186, Part 3:509-19.

[15] Jiang L, Zhu FQ, Wang LW, Liu CZ, Wang RZ. Experimental investigation on a $\mathrm{MnCl}_{2}-\mathrm{CaCl}_{2}-\mathrm{NH}_{3}$ thermal 
energy storage system. Renewable Energy. 2016;91:130-6.

[16] Zhu FQ, Jiang L, Wang LW, Wang RZ. Experimental investigation on a $\mathrm{MnCl}_{2}-\mathrm{CaCl}_{2}-\mathrm{NH}_{3}$ resorption system for heat and refrigeration cogeneration. Applied Energy. 2016;181:29-37.

[17] Jiang L, Wang L, Wang R, Zhu F, Lu Y, Roskilly AP. Experimental investigation on an innovative resorption system for energy storage and upgrade. Energy Conversion and Management. 2017;138:651-8.

[18] Li T, Wang R, Kiplagat JK, Kang Y. Performance analysis of an integrated energy storage and energy upgrade thermochemical solid-gas sorption system for seasonal storage of solar thermal energy. Energy. 2013;50:454-67.

[19] Scapino L, Zondag HA, Van Bael J, Diriken J, Rindt CCM. Sorption heat storage for long-term lowtemperature applications: A review on the advancements at material and prototype scale. Applied Energy. 2017;190:920-48.

[20] Li TX, Xu JX, Yan T, Wang RZ. Development of sorption thermal battery for low-grade waste heat recovery and combined cold and heat energy storage. Energy. 2016;107:347-59.

[21] Li TX, Wang RZ, Yan T. Solid-gas thermochemical sorption thermal battery for solar cooling and heating energy storage and heat transformer. Energy. 2015;84:745-58.

[22] Han JH, Lee KH. Gas permeability of expanded graphite-metallic salt composite. Applied Thermal Engineering. 2001;21(4):453-63.

[23] Jiang L, Wang LW, Jin ZQ, Wang RZ, Dai YJ. Effective thermal conductivity and permeability of compact compound ammoniated salts in the adsorption/desorption process. International Journal of Thermal Sciences. 2013;71:103-10.

[24] Jiang L, Wang LW, Wang RZ. Investigation on thermal conductive consolidated composite $\mathrm{CaCl}_{2}$ for adsorption refrigeration. International Journal of Thermal Sciences. 2014;81:68-75. 
[25] Yan T, Li TX, Li H, Wang RZ. Experimental study of the ammonia adsorption characteristics on the composite sorbent of $\mathrm{CaCl} 2$ and multi-walled carbon nanotubes. International Journal of Refrigeration. 2014;46:165-72.

[26] Veselovskaya JV, Tokarev MM, Grekova AD, Gordeeva LG. Novel ammonia sorbents "porous matrix modified by active salt" for adsorptive heat transformation: 6. The ways of adsorption dynamics enhancement. Applied Thermal Engineering. 2012;37:87-94.

[27] Wang LW, Wang RZ, Oliveira RG. A review on adsorption working pairs for refrigeration. Renewable and Sustainable Energy Reviews. 2009;13(3):518-34.

[28] Wang K, Wu JY, Wang RZ, Wang LW. Composite adsorbent of $\mathrm{CaCl}_{2}$ and expanded graphite for adsorption ice maker on fishing boats. International Journal of Refrigeration. 2006;29(2):199-210.

[29] Sharma R, Kumar EA. A Comparative Thermodynamic Analysis of Gas-Solid Sorption System Based On H2-La0.9Ce0.1Ni5/LaNi4.7Al0.3 and $\mathrm{NH}_{3}-\mathrm{NaBr} / \mathrm{MnCl}_{2}$. Energy Procedia. 2017;109:48-55.

[30] Jiang L, Wang LW, Zhou ZS, Zhu FQ, Wang RZ. Investigation on non-equilibrium performance of composite adsorbent for resorption refrigeration. Energy Conversion and Management. 2016;119:67-74.

[31] Bao HS, Oliveira RG, Wang RZ, Wang LW, Ma ZW. Working pairs for resorption refrigerator. Applied Thermal Engineering. 2011;31(14-15):3015-21.

[32] Jiang L, Wang L, Roskilly AP, Wang R. Design and performance analysis of a resorption cogeneration system. International Journal of Low-Carbon Technologies. 2013;8:85-91.

[33] Gao P, Zhang XF, Wang LW, Wang RZ, Li DP, Liang ZW, et al. Study on $\mathrm{MnCl}_{2} / \mathrm{CaCl}_{2}-\mathrm{NH}_{3}$ two-stage solid sorption freezing cycle for refrigerated trucks at low engine load in summer. Energy Conversion and Management. 2016;109:1-9.

[34] Jiang L, Wang LW, Luo WL, Wang RZ. Experimental study on working pairs for two-stage chemisorption 
freezing cycle. Renewable Energy. 2015;74(0):287-97.

[35] Jiang L, Wang LW, Liu CZ, Wang RZ. Experimental study on a resorption system for power and refrigeration cogeneration. Energy. 2016;97:182-90.

[36] Wang LW, Metcalf SJ, Critoph RE, Thorpe R, Tamainot-Telto Z. Thermal conductivity and permeability of consolidated expanded natural graphite treated with sulphuric acid. Carbon. 2011;49(14):4812-9.

[37] Wang LW, Metcalf SJ, Critoph RE, Thorpe R, Tamainot-Telto Z. Development of thermal conductive consolidated activated carbon for adsorption refrigeration. Carbon. 2012;50(3):977-86.

[38] Zhao YJ, Wang LW, Wang RZ, Ma KQ, Jiang L. Study on consolidated activated carbon: Choice of optimal adsorbent for refrigeration application. International Journal of Heat and Mass Transfer. 2013;67:867-76.

[39] Krishna DJ, Basak T, Das SK. Natural convection in a non-Darcy anisotropic porous cavity with a finite heat source at the bottom wall. International Journal of Thermal Sciences. 2009;48(7):1279-93.

[40] Yan T, Wang RZ, Li TX, Wang LW, Fred IT. A review of promising candidate reactions for chemical heat storage. Renewable and Sustainable Energy Reviews. 2015;43:13-31. 